\title{
PLIO-PLEISTOCENE AMPHIBIANS AND REPTILES FROM CENTRAL TURKEY: NEW FAUNAS AND FAUNAL RECORDS WITH COMMENTS ON THEIR BIOCHRONOLOGICAL POSITION BASED ON SMALL MAMMALS
}

\author{
ELENA SYROMYATNIKOVA ${ }^{1,2, *}$, ALEXEY TESAKOV ${ }^{3}$, SERDAR MAYDA ${ }^{4,5}$, TANJU KAYA $^{5}$, GERÇEK SARAÇ ${ }^{6}$ \\ ' A. A. Borissiak Paleontological Institute, Russian Academy of Sciences, Profsoyuznaya ul. 123, 117647 Moscow, Russia; \\ e-mails: esyromyatnikova@gmail.com, sev@paleo.ru. \\ 2 Zoological Institute, Russian Academy of Sciences, Universitetskaya emb. 1, 199034 St. Petersburg, Russia. \\ ${ }^{3}$ Geological Institute, Russian Academy of Sciences, Pyzhevsky per. 7, 119017 Moscow, Russia; e-mail: tesak@ginras.ru. \\ ${ }^{4}$ Department of Biology, Faculty of Science, Ege University, Bornova, 35100 Izmir, Turkey; e-mail: serdar.mayda@ege.edu.tr. \\ ${ }^{5}$ Ege University, Natural History Museum, 35100 Bornova-Izmir, Turkey. \\ ${ }^{6}$ Sunar Sokak No:3/3 Yenimahalle-Ankara, Turkey. \\ * corresponding author
}

Syromyatnikova, E., Tesakov, A., Mayda, S., Kaya, T., Saraç, G. (2019): Plio-Pleistocene amphibians and reptiles from Central Turkey: new faunas and faunal records with comments on their biochronological position based on small mammals. - Fossil Imprint, 75(3-4): 343-358, Praha. ISSN 2533-4050 (print), ISSN 2533-4069 (on-line).

\begin{abstract}
Small fossil vertebrates from several Pliocene and Pleistocene localities in Central Anatolia (Turkey) are reviewed. Data on small mammals represent assemblages from the early Pliocene (MN 14: Nasrettinhoca 1, 2 and Hamamkarahisar A, B), and late Pliocene (MN 16: Hoyhoytepe 1, 2, 3 and Mercan 1); Early Pleistocene (MN 17: Mercan 2), and Middle Pleistocene (MQ 1/MQ 2: Yenişarbademli). The biochronology related characters of arvicolines Promimomys, Mimomys, Microtus, Lagurus and Clethrionomys are briefly discussed. Data on the systematics of fossil amphibians and reptiles is also described from these localities. The early Pliocene (MN 14) assemblages significantly add to knowledge on the herpetofaunal composition of this stratigraphic level, which until now was poorly characterized in Turkey. Remains of Pelobatidae, Bufonidae, Ranidae, Amphisbaenia and Natricinae are reported for the first time from the MN 14 biozone of Turkey. Palaeobatrachus from Mercan 1 extends the temporal range of this group in the Eastern Mediterranean into the late Pliocene. The described remains of amphibians and reptiles from Turkey span a considerable stratigraphic range from the early Pliocene to the Middle Pleistocene (time interval of about $5 \mathrm{Ma}$ ) and partly fill a gap in the palaeoherpetofaunal record of the Eastern Mediterranean.
\end{abstract}

Key words: amphibians, reptiles, small mammals, Pleistocene, Pliocene, Turkey

Received: March 5, 2019| Accepted: September 18, 2019 | Issued: December 30, 2019

\section{Introduction}

The Plio-Pleistocene fossil record of smaller vertebrates in Anatolia is potentially one the most complete and detailed in Western Asia due to the numerous terrestrial sedimentary basins with continuous depositional records. Stages of mammalian evolution recorded in numerous Plio-Pleistocene localities provide a reliable regional biochronology utilized for creating time models in diverse studies in Earth Sciences. Among the important contributions that set a base for Turkish mammalian palaeontology we consider the review of Sickenberg et al. (1976) for the Neogene, and a series of detailed descriptions of local Aegean-Anatolian Pleistocene faunas by Gerchard Storch (Kuss and Storch 1978, Storch 1975, 1988). Among the seminal publications are the review of Plio-Pleistocene small mammals by Ünay and de Bruijn
(1998), the regional correlation of Neogene biozonation with the standard European biochronology (ELMA-MN units) proposed by Ünay et al. (2003) and de Bruijn et al. (2013), and a series of publications by S. Sen and his colleagues on Neogene and Quaternary small mammal faunas of the region (e.g. Sen 1977, Sen et al. 1991, Erdal et al. 2018, and others).

Long term collecting work by one of the co-authors (G.S.) in Anatolian Neogene and Quaternary deposits resulted in the accumulation of important small vertebrate collections, a part of which is reviewed in this paper. We briefly review small mammals (mostly Arvicolinae) to assess the biochronological position of the faunas. Using this basis, the herpetofauna from these localities is described systematically presenting new information on a number of new records of rare or poorly known taxa. 


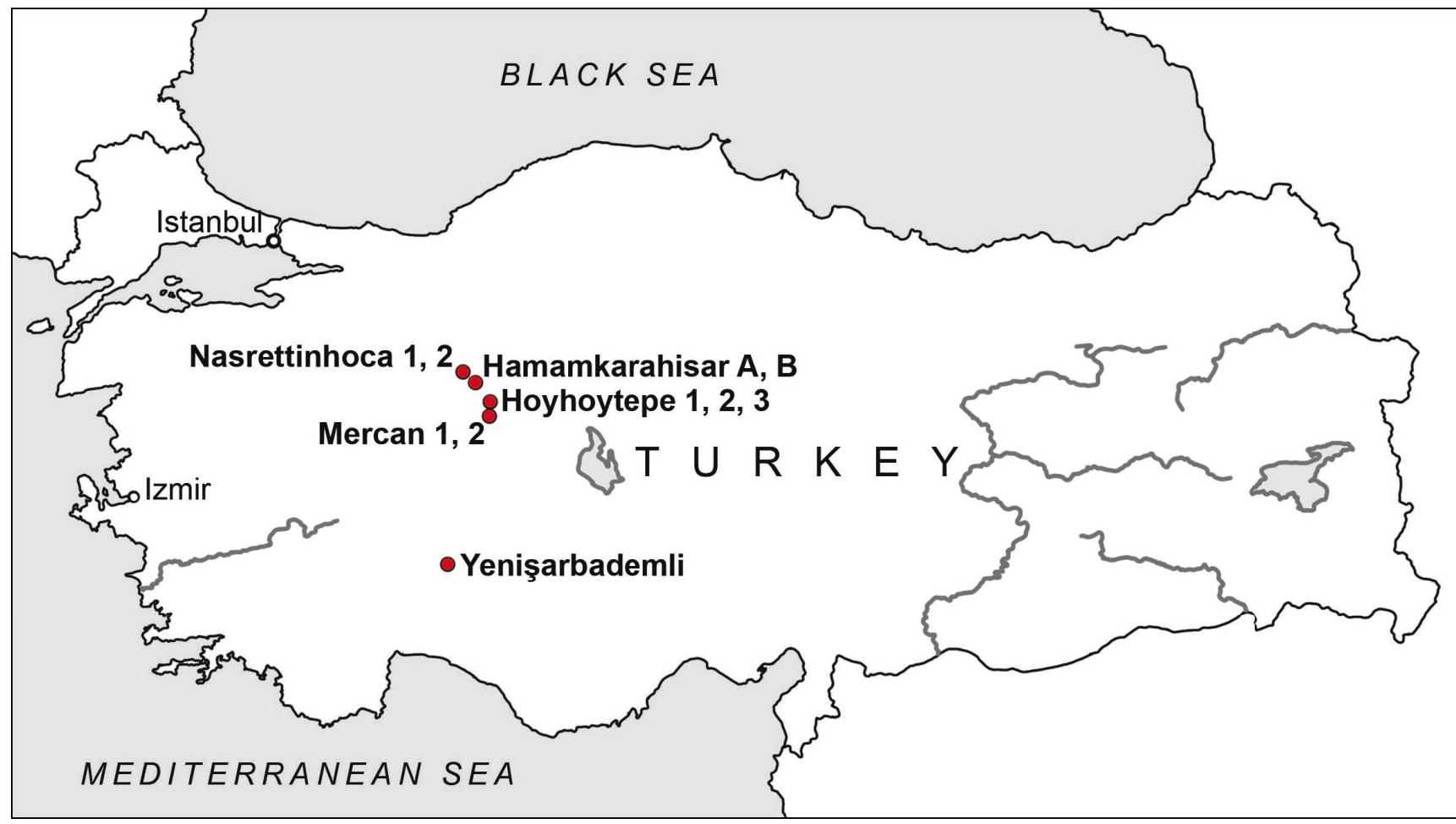

Text-fig. 1. Schematic map of the localities.

The knowledge of the Plio-Pleistocene fossil herpetofaunas in Anatolia is limited to those described from the Pliocene of Çalta (Rage and Sen 1976, Sen and Rage 1979), Çeştepe (Sen et al. 2017), and Ericek (Van den Hoek Ostende et al. 2015a), the Early Pleistocene of Pasinler (Vasilyan et al. 2014), and the Middle Pleistocene of Emirkaya-2 (Venczel and Sen 1994). However, significant progress has been made in the last few years regarding knowledge of Oligo-Miocene reptile material (mostly squamates) from several Turkish localities that were described (Oligocene and Miocene remains of anguids: Ophisaurus, Anguis and undetermined Anguidae; Čerňanský et al. 2017; and Miocene remain of blanid: Blanus cf. strauchi; Georgalis et al. 2018). The diverse early Miocene herpetofaunas were recently described from Kilçak localities (Syromyatnikova et al. 2019). A large contribution to the Miocene amphibians and reptiles of Anatolia was made by Claessens (1995) in his $\mathrm{Ph} . \mathrm{D}$. thesis. Unfortunately, his data remains unpublished with the exception of a brief report (Claessens 1997). However, the Plio-Pleistocene time interval is critical for understanding the origin and distribution of the modern fauna of the area. The study of entire faunal assemblages would further elucidate the taxonomic diversity and patterns of faunal changes during the approximately 5 million years from the early Pliocene to Middle Pleistocene.

Here we describe material on amphibians and reptiles from several Cenozoic Turkish localities of the early Pliocene (MN 14: Nasrettinhoca 1, 2 and Hamamkarahisar A, B), the late Pliocene (MN 16: Hoyhoytepe 1, 2, 3 and Mercan 1), the Early Pleistocene (MN 17: Mercan 2), and the Middle Pleistocene (Yenişarbademli) (see Text-fig. 1, Tab. 1 and Material and methods for details). Although the material is fragmentary, it provides important new information about the assemblages of fossil small vertebrates in Turkey.

\section{Geological setting}

In the Eskişehir-Sivrihisar region, Neogene units were described under different formation names. Some workers described the lacustrine units as the İlyaspaşa (Miocene) and Sakarya (Pliocene) formations, while the same units were also known as Porsuk (Miocene) and Hüyüklü (Pliocene) formations (Gözler et al. 1996), or Sakarya (Miocene) and Porsuk (Pliocene) (Boyraz 2004, Karakaş et al. 2007, Kahraman 2018). We follow the latter version of stratigraphy in our field study.

The name Porsuk Formation is applied to a succession of two distinct lithological sequences: a lower clastic unit, characterized by reddish lithic conglomerate and sandstone fan deposits, which corresponds to the Hisar Formation (Miocene) of Çelik et al. (2013), succeeded by the upper sequence dominated by limestone-mudstone lacustrine deposits that corresponds to the Çakmak and Mercan formations (Miocene) (Çelik et al. 2013). Kahraman (2018) subdivided the Porsuk Formation into four conformably superposed subunits NP1-4. The lower subunit, NP1, is composed of the reddish clastics (NP1 of Kahraman 2018) that host the Nasrettinhoca 3 locality (Text-fig. 2). This locality yielded a fossil large mammal assemblage, containing Ictitherium, Hipparion, Ceratotherium, Gazella and Procapreleous, indicating a late Miocene age (middle - late Turolian, MN 12-13). Both Nasrettinhoca 1, 2 and Hamamkarahisar A, B faunas were collected from the lowermost part of the middle subunit of the Porsuk Formation (NP2 subunit of Kahraman 2018), represented primarily by greyish-greenish limy mudrocks and silty limestone. The upper subunits, NP3 and 4, consist of alternating white thin- to medium-thickness deposits of bedded and clayey limestone. Hoyhoytepe 1, 2, 3 and Mercan 1 faunas were collected 
from the gastropod-bearing clayey limestone horizons in the middle part of subunit NP3. Mercan 2 material was collected from greenish limy claystone horizons of the uppermost part of NP3 (Text-fig. 2).

Contrary to the aforementioned vertebrate faunas of Sivrihisar region, the Isparta-Beyşehir-Yenişarbademli fossil assemblage was collected from a typical fissure-filling, exposed in a road-cut, west of the town of Yenişarbademli. All fissure-fillings around Yenişarbademli are in neritic Jurassic limestones.

\section{Material and methods}

All the studied localities were found by one of the authors (G.S.) in the 1990s and were visited and sampled several times (during non-regular and short-term excavations) by EUNHM teams between 2000-2012. The material was collected by wet screening of sediments (approximately 2-3 tons), using a set of screens. The smallest screen had a $0.5 \mathrm{~mm}$ mesh. In subsequent years, the fossils were sorted and classified under a stereomicroscope. Approximately 150

Table 1. Taxonomic composition of Plio-Pleistocene vertebrate localities of Central Turkey.

\begin{tabular}{|c|c|c|c|c|c|c|c|c|c|c|}
\hline Age & & & & & & & & & MN 17 & MQ 1/2 \\
\hline Taxon/Locality & 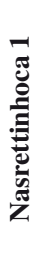 & 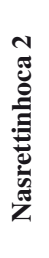 & 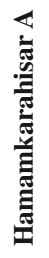 & 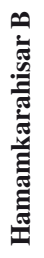 & $\frac{\overrightarrow{0}}{\frac{0}{0}}$ & 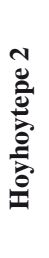 & $\begin{array}{l}m \\
\frac{0}{0} \\
\frac{0}{0} \\
\frac{0}{0}\end{array}$ & 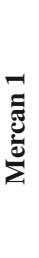 & 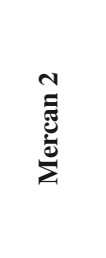 & 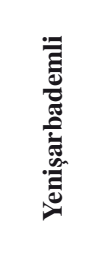 \\
\hline Latonia sp. & - & + & - & - & - & - & - & - & - & - \\
\hline Palaeobatrachus sp. & - & - & - & - & - & - & - & + & - & - \\
\hline Pelobates sp. & - & + & - & - & - & - & - & - & - & - \\
\hline Bufotes viridis & - & + & - & - & - & - & - & - & - & - \\
\hline Pelophylax sp. & + & - & + & - & + & + & + & + & + & - \\
\hline Ranidae indet. & - & - & + & - & - & - & - & - & - & - \\
\hline Amphisbaenia & + & - & - & - & - & - & - & - & - & - \\
\hline Lacertidae & + & - & - & - & - & - & - & - & - & - \\
\hline Natrix/Natricinae & - & + & - & + & - & - & - & - & - & + \\
\hline cf. Colubrinae & - & - & - & - & - & - & - & - & - & + \\
\hline Desmaninae & - & - & - & - & + & + & + & + & + & - \\
\hline Soricidae & - & - & - & - & - & + & - & - & - & + \\
\hline Beremendia sp. & - & - & - & - & - & - & - & - & + & - \\
\hline Leporidae & - & + & - & - & - & - & - & - & - & - \\
\hline Trischizolagus sp. & - & - & - & + & - & - & - & - & - & - \\
\hline Ochotona sp. & + & + & - & - & - & - & - & - & - & + \\
\hline Myomimus sp. & - & - & - & - & - & - & - & - & - & + \\
\hline Dryomys sp. & - & - & - & - & - & - & - & - & - & + \\
\hline Apodemus sp. & + & + & - & - & - & - & - & - & + & + \\
\hline Occitanomys sp. & - & + & - & - & - & - & - & - & - & - \\
\hline Micromys sp. & - & - & - & - & - & + & - & - & - & - \\
\hline Orientalomys similis & - & - & - & - & - & + & - & - & - & - \\
\hline Cricetulus sp. & - & - & - & - & - & - & - & - & - & + \\
\hline Mesocricetus sp. & - & - & - & - & - & - & - & - & - & + \\
\hline Promimomys cf. insuliferus & - & + & - & - & - & - & - & - & - & - \\
\hline Promimomys sp. & - & - & + & + & - & - & - & - & - & - \\
\hline Mimomys ex gr. stehlini-hintoni & - & - & - & - & - & - & - & - & + & - \\
\hline Mimomys hajnackensis & - & - & - & - & + & + & + & + & - & - \\
\hline Microtus ex gr. arvalis-socialis & - & - & - & - & - & - & - & - & - & + \\
\hline Microtus cf. guentheri & - & - & - & - & - & - & - & - & - & + \\
\hline cf. Chionomys nivalis & - & - & - & - & - & - & - & - & - & + \\
\hline Lagurus transiens & - & - & - & - & - & - & - & - & - & + \\
\hline Clethrionomys acrorhiza & - & - & - & - & - & - & - & - & - & + \\
\hline
\end{tabular}




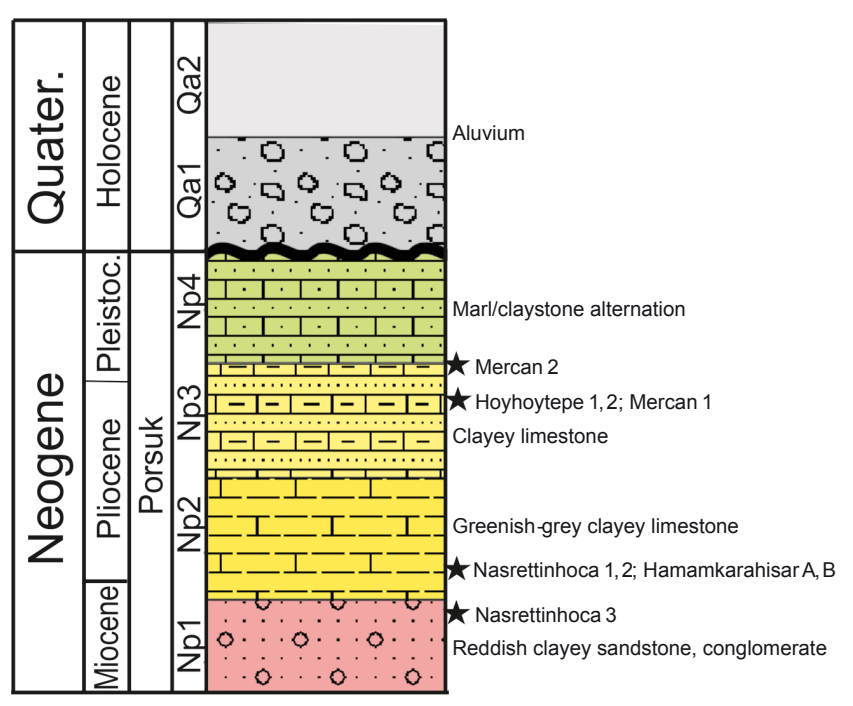

Text-fig. 2. Stratigraphic column of the Eskișehir-Sivrihisar region (Central Turkey). The regional stratigraphy follows Kahraman (2018). Stars mark the positions of vertebrate localities.

small vertebrate remains were recovered, about 60 of which are assigned to amphibians and reptiles. The large mammal collections from the studied faunas are under study by the EUNHM team. All small vertebrate materials are stored in the palaeovertebrate collections of the Natural History Museum of the Ege University in Izmir, Turkey (EUNHM PV).

The material comes from the following localities (Textfig. 1):

- Nasrettinhoca 1,2 (= Eskişehir Sivrihisar-Nasrettinhoca),

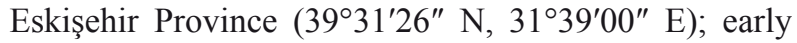
Pliocene, MN 14;

- Hamamkarahisar A, B (= Eskişehir SivrihisarHamamkarahisar), Eskişehir Province (39²7'57" N, $31^{\circ} 44^{\prime} 07^{\prime \prime}$ E); early Pliocene, MN 14;

- Hoyhoytepe 1, 2, 3 (= Eskişehir Sivrihisar-Mercan), Eskişehir Province $\left(39^{\circ} 21^{\prime} 46^{\prime \prime} \mathrm{N}, 31^{\circ} 54^{\prime} 47^{\prime \prime} \mathrm{E}\right)$; late Pliocene, MN 16;

- Mercan 1 (= Eskişehir Sivrihisar-Mercan), Eskişehir Province $\left(39^{\circ} 20^{\prime} 16^{\prime \prime} \mathrm{N}, 31^{\circ} 55^{\prime} 17^{\prime \prime} \mathrm{E}\right)$; late Pliocene, MN 16;

- Mercan 2 (= Eskişehir Sivrihisar-Mercan), Eskişehir Province (39²0'16" N, 31 ${ }^{\circ} 55^{\prime} 17^{\prime \prime}$ E); Early Pleistocene, MN 17;

- Yenişarbademli, Isparta Province (37²4'35" N 31 $22^{\prime} 57^{\prime \prime}$ E); Middle Pleistocene.

The specimens were photographed using a scanning electron microscope (Tescan Vega-II XMU) in the Paleontological Institute of the Russian Academy of Sciences in Moscow (Russia) and a Leica M165 C binocular microscope with an axially mounted DFC425 camera (using a focus stacking technique combined with Helicon Focus software version 7.0.1). The osteological terminology for herpetofauna mainly follows Böhme (1977), Sanchiz (1998) and Gómez and Turazzini (2016) for anurans, Roček (1984) and Szyndlar (1984) for squamates. Dental terminology for arvicolids follows Van der Meulen (1973) for occlusal elements, and Rabeder (1981) for linea sinuosa (dentin tracts).
The terminology of the European mammal biochronology used here follows Fejfar et al. (1998) for mammal ages and MN-MQ zones, and the regional zonation for the Pliocene follows Ünay et al. (2003) and de Bruijn et al. (2013).

\section{Small mammals and biochronology of the studied sites}

The oldest level found in the described material is represented by faunas of Nasrettinhoca 1 and 2 (Text-fig. $3 \mathrm{a}-\mathrm{c})$. The age of these assemblages is clearly defined by the presence of a primitive vole belonging to the grade of Promimomys insuliferus KowALsKI. Three available molars show low dentin tracts not higher than $0.25 \mathrm{~mm}$, a large posterior lobe of the two-islet M3, BSA2 that is laterally protruding further than BSA1 in $\mathrm{M} 2$, and the protocone root of M1 which is closer to the hypocone than to the anteroconule (Text-fig. 3c2).

Only two relatively well illustrated finds of the most primitive Promimomys are recorded from Turkey. The record from Dinar-Akçaköy was originally referred to Promimomys (Sickenberg et al. 1975). It was recently redescribed as Promimomys enginae (Suata-Alpaslan 2015). This vole strongly deviates from the typical $P$. insuliferus and in $\mathrm{ml}$ displays the characters of Germanomys. The scanty material of a primitive vole from İğdeli (Suata-Alpaslan et al. 2010) fits the type material of $P$. insuliferus from Podlesice, the type fauna of the early Ruscinian (Kowalski 1956, Agajanian and Kowalski 1978). Other records of primitive Promimomys from Turkey mentioned in the literature (Sickenberg et al. 1975, Ünay et al. 2003), such as Babadat and Kangal 2, need a detailed published description. The Nasrettinhoca 2 fauna is correlated to the early Ruscinian, biochron MN 14, and regional zone M of Ünay et al. (2003). The assemblage of Nasrettinhoca 1 is too poor for any reliable age determinations. Nevertheless, its composition (Apodemus, Ochotona) and a close stratigraphic position to the former locality indicate a similar geological age.

Hamamkarahisar A and B. The very scanty and poorly preserved vole remains preclude a reliable taxonomic judgment. The morphology of a single complete M1 of a primitive Promimomys from level B (Text-fig. 3d), where it co-occurs with cf. Trischizolagus, implies a possible correlation to MN 14 supported by the stratigraphic position of the sites close to the level of Nasrettinhoca 1 and 2.

The assemblages of Hoyhoytepe 1, 2, 3 document a faunal stage of the late Pliocene (Piacenzian). All three levels yielded desmanines and a larger Mimomys vole similar to $M$. hajnackensis. These voles show low dentin tracts, well developed negative (Mimomys type) enamel differentiation, moderate amount of cement, acrorhiz condition of posterior root of $\mathrm{m} 2$, elongated posterior enamel islet and two roots in M3 (Text-fig. 3e-f). The presence of Orientalomys similis with three roots in $\mathrm{m} 1$, and a larger Micromys sp. support the early Villanyian age of the faunas. The assemblages are attributable to biochron MN 16a, and regional Anatolian zone O (Ünay et al. 2003).

The Mercan 1 assemblage also includes remains of $M$. hajnackensis (Text-fig. 3h) and can be correlated with the early Villanyian, biochron MN 16a, and regional Anatolian zone O. 

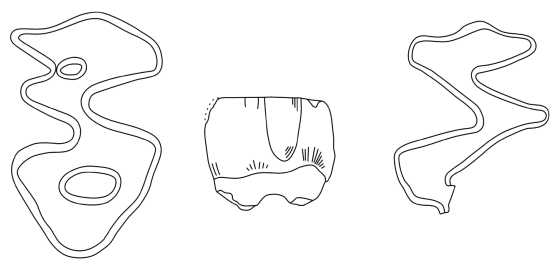

a2

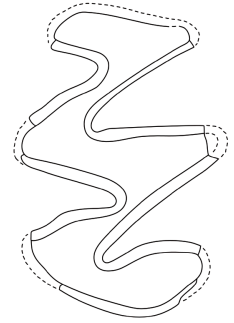

c1

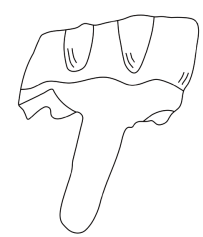

c2

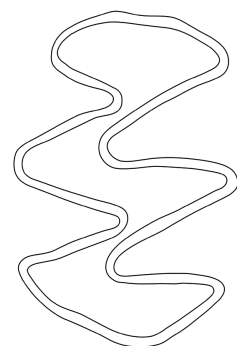

d1

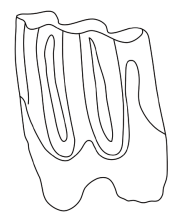

f2

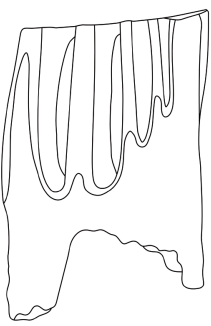

j2 e3
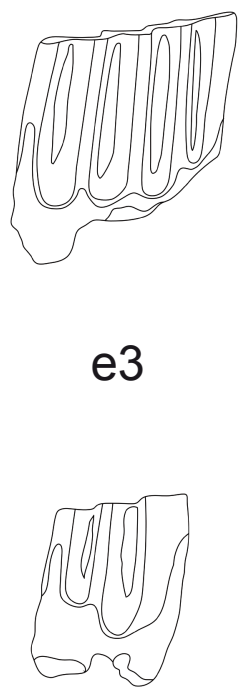

f3

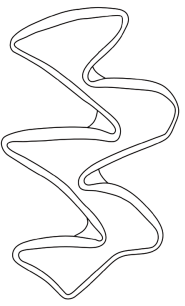

g1

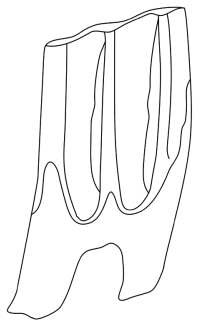

g2

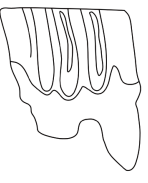

h2

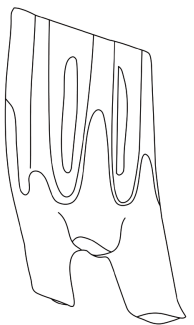

g3

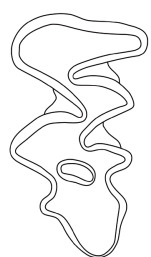

h1
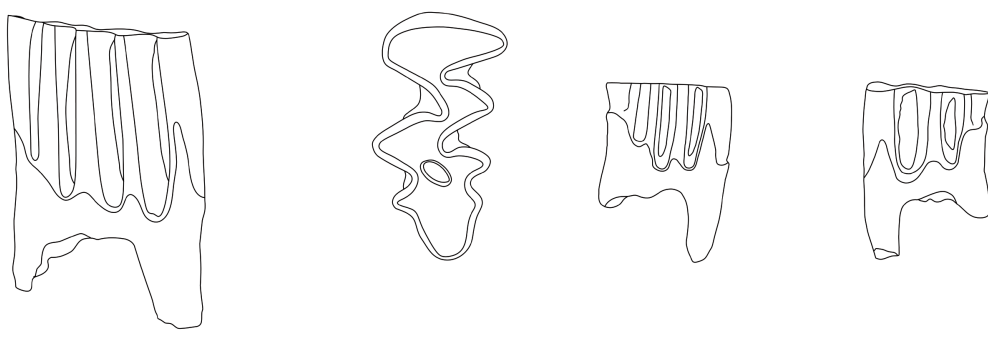

i1

j3

i2

i3

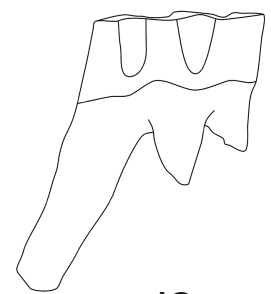

d2

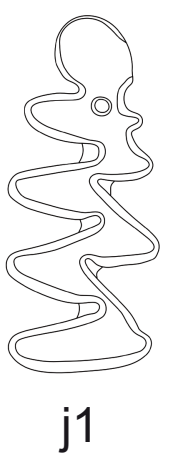

Text-fig. 3. Arvicolids from Plio-Pleistocene sites of Eskișehir-Sivrihisar region (Central Turkey). a-c - Promimomys cf. insuliferus from Nasrettinhoca 2: a - M3 dex., EUNHM PV-13200; b - fragmentary M2 sin., EUNHM PV-13201; c - M1 sin., EUNHM PV-13202; d - Promimomys sp. from Hamamkarahisar B, M1 sin., EUNHM PV-13203; e-i - Mimomys cf. hajnackensis: e, f Hoyhoytepe 2, m1-m2 from the same mandibular tooth row: e - m1 sin., EUNHM PV-13204; f - m2 sin., EUNHM PV-13205; g, h - Mercan 1: g - M1 dex., EUNHM PV-13206; h - M3 sin., EUNHM PV-13207; i - Hoyhoytepe 3, M3 sin., EUNHM PV-13208; j-Mimomys ex gr. stehlini-hintoni from Mercan 2, M1 dex., EUNHM PV-13209 in lingual view (j2) and labial (j3) views. Scales for occlusal (larger), and lateral (smaller) views equal $1 \mathrm{~mm}$.

The Mercan 2 assemblage clearly documents a younger level characterized by a smaller species Mimomys cf. hintoni-stehlini (Text-fig. 3j). This level can be tentatively correlated to the early/late Villanyian transition, biochrons MN 16b/MN 17, in the early part of the regional Anatolian zone P (Ünay et al. 2003).

Yenişarbademli. The only microvertebrate assemblage in this study that originated from cave deposits documents a Middle Pleistocene fauna. The small mammals of this fauna include larger and smaller Microtus species with well separated triangles $\mathrm{T} 4$ and $\mathrm{T} 5 \mathrm{in} \mathrm{m} 1$. As shown by the scanty material available, the upper third molars are represented by simplified morphotypes. The smaller form (Text-fig. 4a-e) conforms to the morphology of the Microtus arvalis group, but the M3 shows a predominant simplex morphotype and a single principalis condition (Text-fig. 4c-e) sensu Rörig 


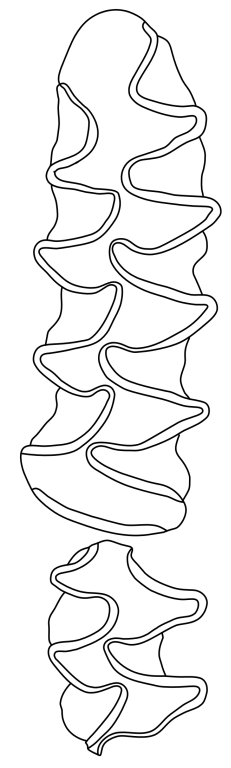

a

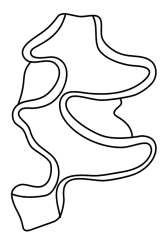

b

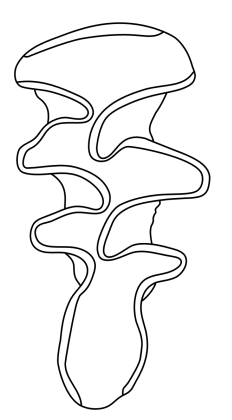

C

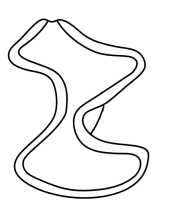

k1

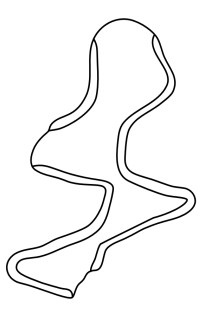

g

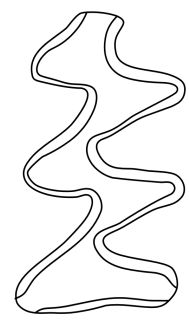

i

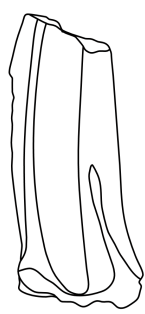

k2

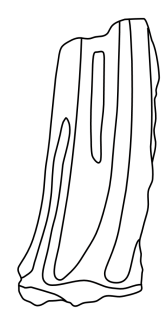

k3

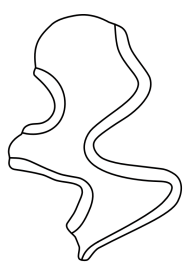

h
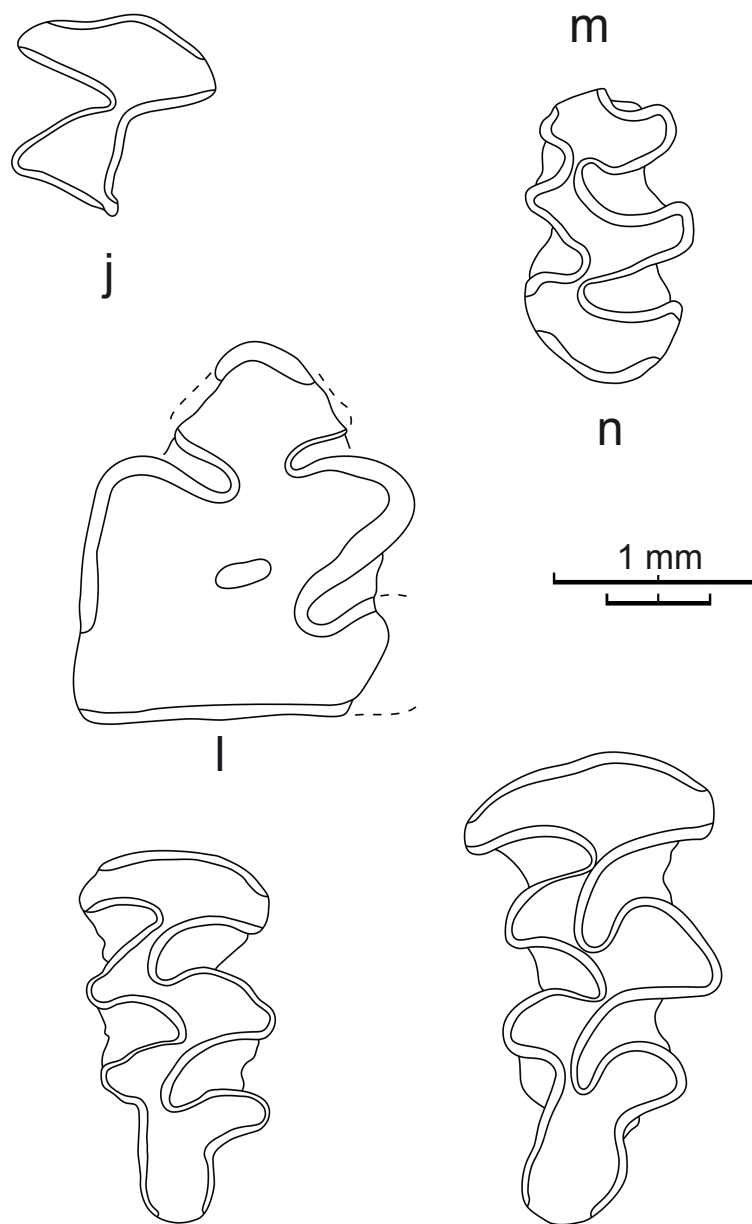

O

$\mathrm{m}$

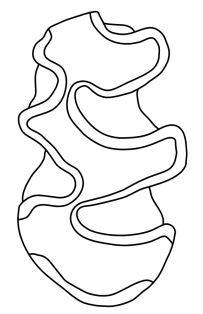

$\mathrm{n}$ $1 \mathrm{~mm}$

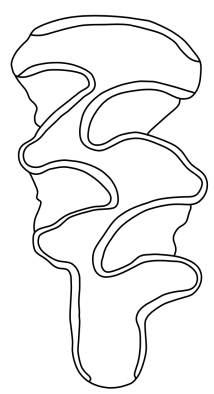

f
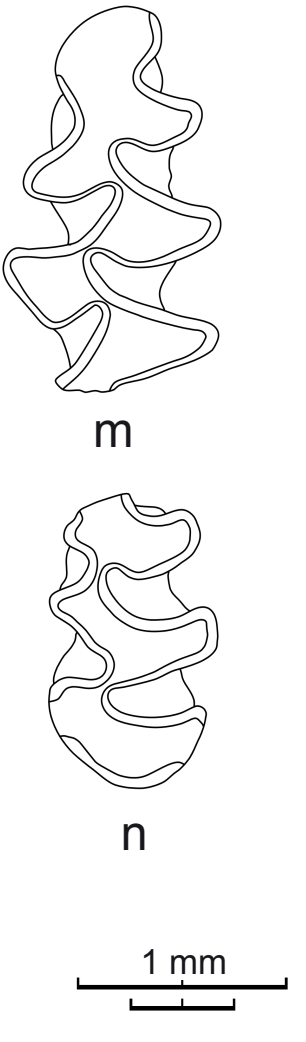

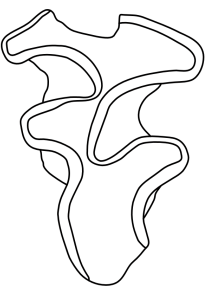

d

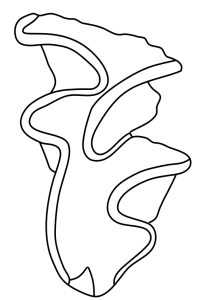
e

Text-fig. 4. Small mammals from Middle Pleistocene site of Yenişarbademli (Central Turkey). a-e - Microtus ex gr. arvalis-socialis: a - $\mathbf{m} 1$ and fragmentary $\mathrm{m} 2$ sin., EUNHM PV-13210; b - fragmentary m3 sin., EUNHM PV-13211; c - M3 dex., EUNHM PV13212a; d, e - fragmentary M3 dex., EUNHM PV-13212b, EUNHM PV-13212c; f - cf. Chionomys nivalis, M3 dex., EUNHM PV-13213; g-j - Lagurus transiens: g, h - fragmentary m1 sin., EUNHM PV-13214-13215; i - m2 sin., EUNHM PV-13216; j fragmentary M2 dex., EUNHM PV-13217; k - Clethrionomys cf. acrorhiza, fragmentary m3 sin., EUNHM PV-13218 in labial (k2) and lingual (k3) views; I - Ochotona sp., non-pussiloid form, p3 dex., EUNHM PV-13219; m-o - Microtus cf. guentheri: m - fragmentary m1 sin., EUNHM PV-13220; n - m3 sin., EUNHM PV-13221; o - M3 dex., EUNHM PV-13222. Scales for occlusal (larger), and lateral (smaller) views equal $1 \mathrm{~mm}$.

and Börner (1905). In recent populations the principalis condition is overwhelmingly dominant. Noteworthy is the relatively well developed T4 in lower m3 (Text-fig. 4b) of the smaller Microtus form. This morphology is known to differentiate nominotypical Microtus (strongly reduced T4) and the social vole group (Sumeriomys) with retained well developed T4 (Baryshnikov and Baranova 1983). An example of the plesiomorphic structure of $\mathrm{m} 3$ assigned to Microtus arvalis from the Middle Pleistocene site of
Üçağızlı Cave can be found in Erdal et al. (2018: fig. 5B:15). Bearing in mind the reviewed characters, we identify the smaller form of Microtus as M. ex gr. arvalis-socialis, as a possible predecessor of either of the several species of Microtus (Microtus) and Microtus (Sumeriomys) in the modern fauna of Anatolia (Kryštufek and Vohralik 2005). A single M3 of a medium-size microtoid vole (Text-fig. 4f) may be indicative of the snow vole Chionomys nivalis. The larger form (Text-fig. $4 \mathrm{~m}-\mathrm{o}$ ) is identified as Microtus 
cf. guentheri because the single M3 (Text-fig. 4o) assigned to this form shows a morphotype simplex (sensu Rörig and Börner 1905) not typical of modern and Late Pleistocene samples of this species. Lagurine voles are represented by several mostly incomplete molars with well-developed positive enamel differentiation (Text-fig. $4 \mathrm{~g}-\mathrm{j}$ ). The two anteroconid parts of lower $\mathrm{m} 1$ (Text-fig. $4 \mathrm{~g}, \mathrm{~h}$ ) show wellseparated anteroconid triangles and a simple anteroconid with developed labial (BRA4) and almost absent lingual reentrant LRA5. This structure is known as one of the characteristic morphotypes ("posterius") of Lagurus transiens (Rekovets and Nadachowski 1995). A lower m2 with an obtuse and short anterior part of T4 (Text-fig. 4i) and a fragmentary M2 with a poorly expressed lagurine denticle in LRA2 (Text-fig. 4j) add to the image of relatively primitive morphology in this vole. A single specimen of Clethrionomys is represented by an incomplete $\mathrm{m} 3$ (Textfig. 4k). Dentin tracts on the posterior lobe are medium high (hyposinuid (HSD), 1.2; hyposinulid (HSLD), 1.55), outside the variability (min-mean-max) of the extant bank vole $C$. glareolus in central European Russia (HSD: 1.65-1.99-2.3; HSLD: $1.50-1.82-2.1 ; \mathrm{n}=30$ ) but above the mean values of the Early Pleistocene C. kretzoii from Schernfeld (Carls and Rabeder 1988). We tentatively assign this form to $C$. acrorhiza, the European Middle Pleistocene chronospecies of the lineage. The fauna of Yenişarbademli also includes remains of a non-pussiloid pika (Text-fig. 4l), absent in the modern fauna of central Anatolia, and dormice Myomimus and Dryomys.

The Middle and Late Pleistocene faunas of the AegeanAnatolian region are known from several well studied reference assemblages. These faunas include mostly modern arvicolids and are differentiated by taxonomic composition and relative advancement of vole species. Among the oldest Middle Pleistocene faunas of the region is that of the Yarımburgaz Cave (Santel and von Koenigswald 1998) in Turkish Thrace, including the steppe lagurine with transitional transiens-lagurus morphotypes of $\mathrm{m} 1$.

After the extinction of the Early Pleistocene lagurine voles, including the endemic Kalymnomys, and more wide spread Lagurodon arankae (e.g. Kuss and Storch 1978, Van den Hoek Ostende et al. 2015b), the Aegean-Anatolian region was regularly occupied by a pulsating distribution range of the Eurasian phyletic lineage of the modern steppe lagurine Lagurus lagurus. This modern species, L. lagurus, is documented from the Latomi-1 fissure filling fauna from Chios Island (Storch 1975), fissure filling of Arnissa in northern Greece (Mayhew 1978) and a number of other sites in Greece (Koufos 2001, Doukas and Papayianni 2016). Questionable Middle - Late Pleistocene records of lagurines in Anatolian Turkey are reported without description from a few sites such as Lagurini indet. from the Middle Pleistocene lacustrine site of Gölbaşı (Suata-Alpaslan 2011), and "Lagurus pannonicus" from the fissure filling of Emirkaya-2 (Sen et al. 1991). The latter record was not supported in a subsequent contribution to this fauna (Montuire et al. 1994). Thus Lagurus transiens from Yenişarbademli is apparently the first reliable record of this form in Anatolia. It clearly dates the fauna to the early Middle Pleistocene. The absence of Mimomys/Arvicola remains in the fauna undermines the possibility of a direct correlation to the latest Biharian (MQ 1) or earliest Toringian (MQ 2), and the overall evolutionary level of the arvicoline fauna implies that the fauna is close to the Biharian/Toringian transition which is estimated to be approximately 0.6 Ma (Maul and Parfitt 2010).

The biochronological positions of the studied assemblages are shown in Text-fig. 7.

\section{Systematic palaeontology}

\author{
Order Anura Fischer, 1813 \\ Family Alytidae Fitzinger, 1843
}

Genus Latonia MeYer, 1843

Latonia sp.

Text-fig. 5a, b

Material. Two ilia, EUNHM PV-13223-13224, Nasrettinhoca 2, early Pliocene, MN 14.

Description. The specimens are represented by two fragmentary left ilia (Text-fig. 5a, b). The largest one (Text-fig. 5b) is represented by a posterior part of the shaft and anterior part of the acetabular fossa. The preserved part of the dorsal crest is thin and dorsoventrally inclined. Though fragmentary, the dorsal acetabular expansion (= pars ascendens) is prominent, whereas the ventral acetabular expansion (= pars descendens) is small. The dorsal tubercle (= tuber superior) is well developed and anteriorly elongated and projects dorsolaterally from the outline of the bone. It is located dorsal to the acetabular fossa. The tubercular fossa is deep. Two foramina pierce the bottom of the tubercular fossa. The anterior margin of the acetabular fossa is prominent laterally. The smaller ilium (Text-fig. $5 \mathrm{a}$ ) is better preserved but seemingly belonged to a juvenile specimen. It is missing the dorsal crest and most of the dorsal tubercle. The ilioischiadic juncture (= junctura ilioischiadica) is expanded ventrally with an interiliac tubercle (= tuber interiliacus; visible in the smaller specimen; Text-fig. 5a3).

Remarks. Latonia is most closely related to Discoglossus (subfamily Discoglossinae; e.g. Sanchiz 1984). Sometimes it is generally difficult to discriminate between these two genera, especially juvenile Latonia and adult Discoglossus. The ilia (especially the smaller one, Text-fig. 5a) from Nasrettinhoca 2 are relatively small in size. But they can be assigned to Latonia based on the small ventral acetabular expansion, prominent anterior margin and low posterior margin of the acetabular fossa (Roček 2013). Fossil and recent Discoglossus are unknown in Turkey.

\section{Family Palaeobatrachidae CoPE, 1865}

\section{Genus Palaeobatrachus TsCHUDI, 1838}

\section{Palaeobatrachus sp.} Text-fig. 5c

M a t e r i a 1. One angular, EUNHM PV-13225, Mercan 1, late Pliocene, MN 16.

Description. The specimen is represented by a fragment of a single left angular without the anterior and posterior extremities. The angular is robust and sigmoid in 


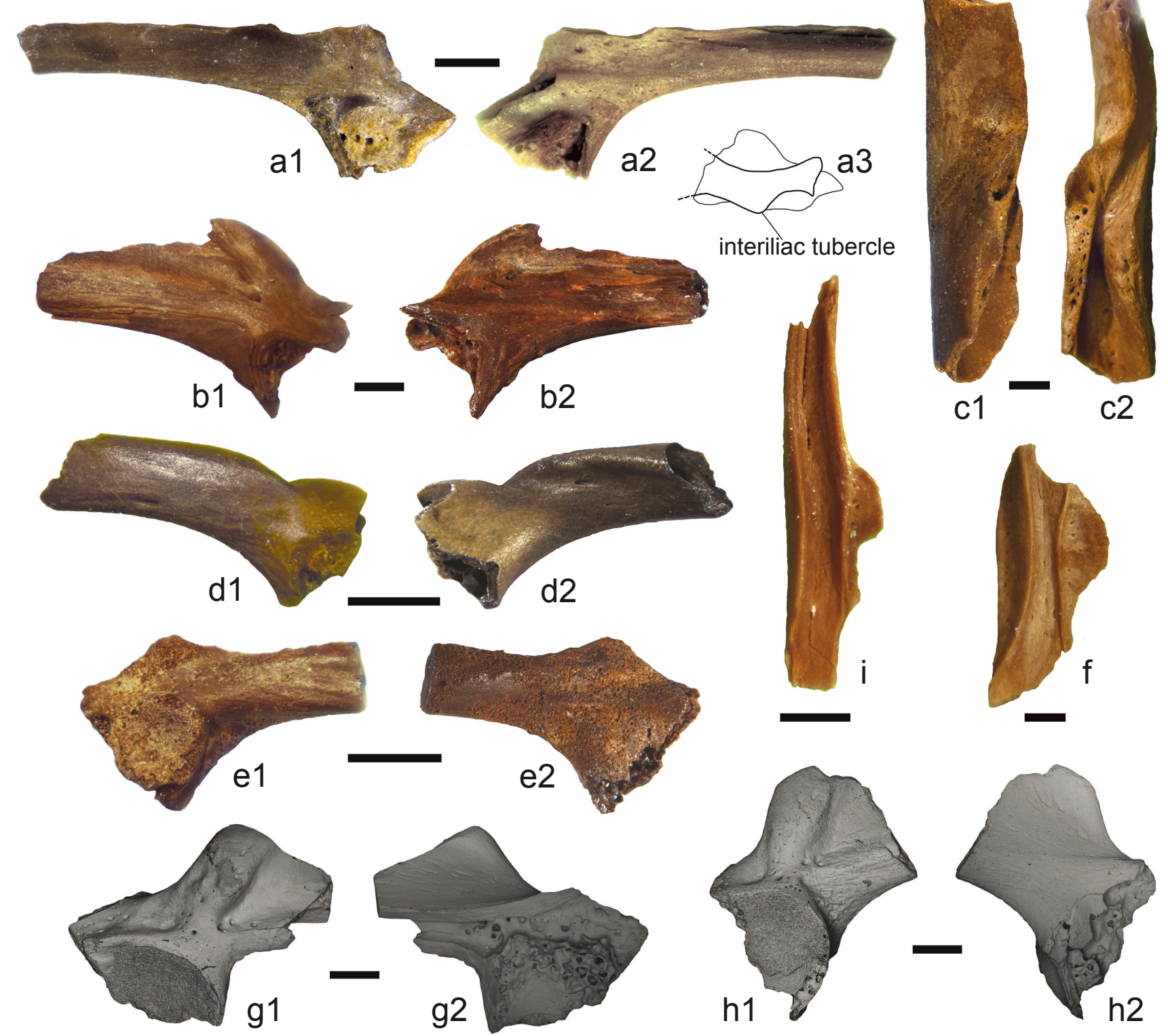

Text-fig. 5. Amphibians: a, b - Latonia sp. from Nasrettinhoca 2: a - left ilium in lateral (a1) and medial (a2) views, and junctura ilioischiadica (a3), EUNHM PV-13223; b - left ilium in lateral (b1) and medial (b2) views, EUNHM PV-13224; c - right angular of Palaeobatrachus sp. from Mercan 1, in medial (c1) and dorsal (c2) views, EUNHM PV-13225; d - left ilium of Pelobates sp. from Nasrettinhoca 2 in lateral (d1) and medial (d2) views, EUNHM PV-13226; e - right ilium of Bufotes viridis s. l. from Nasrettinhoca 2 , in lateral (e1) and medial (e2) views, EUNHM PV-13227; $f$ - left angular of Pelophylax sp. from Mercan 1, in dorsal view, EUNHM PV-13228; g - right ilium of Pelophylax sp. from Mercan 1, in lateral (g1) and medial (g2) views, EUNHM PV-13229; h - right ilium of Pelophylax sp. from Hoyhoytepe 1, in lateral (h1) and medial (h2) views, EUNHM PV-13234; i - left angular of Ranidae indet. from Hamamkarahisar A, in dorsal view, EUNHM PV-13237. Scale equals 1 mm.

shape. The coronoid process is dorsoventrally compressed (as in other palaeobatrachids) and concave dorsally (Roček 2013). It is not restricted posteriorly and continues as a dorsally flat ridge. The groove for Meckel's cartilage is markedly narrowed at the level of the coronoid process.

$\mathrm{R} \mathrm{e} \mathrm{m}$ ar k s . The specimen is assigned to Palaeobatrachidae based on the robustness of the bone and shape of the coronoid process. Since Albionbatrachus (the second genus within Palaeobatrachidae) is known only from the Eocene and Oligocene (Meszoely et al. 1984, Venczel et al. 2013), we provisionally assigned the palaeobatrachid from Mercan 1 to Palaeobatrachus.
Family Pelobatidae BonAPARTE, 1850

Genus Pelobates WAgLer, 1830

Pelobates sp.

Text-fig. $5 \mathrm{~d}$

Material. One ilium, EUNHM PV-13226, Nasrettinhoca 2, early Pliocene, MN 14.

Description. The specimen is represented by a fragmentary left ilium. The anterior part of the acetabular portion and posterior part of the shaft is preserved. It shows the absence of a crista dorsalis, tuber superior, and both 
preacetabular and supracetabular fossae. In dorsal view, a well-marked spiral groove is observable between the iliac shaft and acetabular fossa. It continues on the medial surface of the shaft. The pars ascendens and pars descendens are incomplete.

Re marks. The specimen is assigned to Pelobatidae and Pelobates based on the absence of a crista dorsalis, tuber superior, both preacetabular and supracetabular fossae, and presence of a well-marked spiral groove. Pelobatids comprise two genera: Pelobates Wagler, 1830 (Oligocene Recent of Europe; Recent of Northern Africa and the Middle East) and Eopelobates PARKER, 1929 (Eocene of North America; Eocene - Pliocene of Europe) (Roček et al. 2014). A deep spiral groove between the iliac shaft and acetabulum in the ilium from Nasrettinhoca 2 points to Pelobates rather than Eopelobates. Though the only species of pelobatids, Pelobates syriacus, is known from the region of modern day Turkey (see, e.g. Blain et al. 2016), we abstain from any specific identification.

\section{Family Bufonidae GraY, 1825}

\section{Genus Bufotes RAFInesque, 1815}

\section{Bufotes viridis (LAURENTI, 1768) species group Text-fig. 5e}

Material. One ilium, EUNHM PV-13227, Nasrettinhoca 2, early Pliocene, MN 14.

Description. The specimen is represented by a fragmentary right ilium with complete acetabular portion and posterior part of the iliac shaft. The iliac shaft is thick and rod-like. It is devoid of a dorsal crest (= crista dorsalis) as in all bufonids. The dorsal tubercle (= tuber superior) is high and symmetrical. It is not divided into two tubercles as occurs in some taxa of the $B$. viridis species group. The preacetabular fossa (= fossa praeacetabularis) is well-developed. The pars ascendens and descendens are very narrow.

$\mathrm{R} \mathrm{e} \mathrm{m} \mathrm{a} \mathrm{r} \mathrm{k} \mathrm{s.} \mathrm{The} \mathrm{specimen} \mathrm{is} \mathrm{assigned} \mathrm{to} \mathrm{Bufonidae} \mathrm{and}$ the $B$. viridis species group based on the absence of a dorsal crest, presence of a distinct dorsal tubercle, and presence of a well-developed preacetabular fossa. The Bufo viridis species group (or Bufo viridis sensu lato) is widely distributed extending from Central Europe to Central Asia. The green toads from the Balkans, Anatolia and Caucasus are assigned to B. variabilis (PALLAS, 1769) (see Stöck et al. 2006, 2008). But there are no osteological characters allowing the specific identification of B. variabilis and other recognized species of the $B$. viridis species group. Due to this situation and the fragmentary material from Nasrettinhoca 2, we assign the specimen to the Bufotes viridis species group.

Family Ranidae RAFINESQUe, 1814

Genus Pelophylax Fitzinger, 1843

\section{Pelophylax sp. \\ Text-fig. 5f-h}

Material. One angular, one ilium, EUNHM PV13228, 13229, Mercan 1, late Pliocene, MN 16; one angular, one ilium, EUNHM PV-13230, 13231, Mercan 2, Early Pleistocene, MN 17; one ilium, EUNHM PV-13232,
Nasrettinhoca 1, early Pliocene, MN 14; one ilium, EUNHM PV-13233, Hamamkarahisar A, early Pliocene, MN 14; three ilia, EUNHM PV-13234, 13235, 13236, Hoyhoytepe 1, 2, and 3, late Pliocene, MN 16.

Description. The angulars are preserved only as small pieces including the coronoid process. The specimens are somewhat sinuous. The coronoid process is prominent having a concave dorsal surface with weak rugosity. The crista mandibulae externa is sharp. Laterally, the bone has a deep depression above the crista mandibulae externa. The groove for Meckel's cartilage is wide but markedly constricted at the level of the coronoid process. The coronoid process is rectangular and crinkled dorsally. All ilia are fragmentary, having only the anterior part of the acetabular portion and posterior part of the shaft. The dorsal crest, pars ascendens and pars descendens are mostly missing. The supraacetabular and tubercular fossae are well developed and relatively wide. In the best preserved ilia the dorsal tubercle is robust and prominent. It is located anteriorly to the acetabulum. In the posterior half of its length the dorsal tubercle is distinctly thickened. Laterally the dorsal tubercle is flattened.

Remarks. The specimens are assigned to the genus Pelophylax based on the sharp crista mandibulae externa, dorsally crinkled coronoid process of the angulars and laterally flattened dorsal tubercle of the ilia (see Bailon 1999, Böhme 2001, Ratnikov 2001). In Turkey several living species of Pelophylax (P. caralitanus (ARIKAN, 1988), P. bedriagae (CAmerano, 1882), and $P$. ridibundus (Pallas, 1771)) and one fossil species (Pelophylax barani (RÜCKERT-ÜLKÜMEN, 1980)) are distinguished. Due to the poorly known or missing osteological characteristics of the extant species, it is currently impossible to determine to which of them the specimens from Mercan 1, 2, Nasrettinhoca 1, Hamamkarahisar A and Hoyhoytepe 1, 2, and 3 should be referred.

\section{Ranidae indet. Text-fig. 5 i}

Material. One angular, EUNHM PV-13237, Hamamkarahisar A, early Pliocene, MN 14.

Description. The angular is slightly S-shaped and lacks the anterior and posterior sections. The coronoid process is nearly rectangular and smooth dorsally (without rugosity). The groove for Meckel's cartilage is approximately equally widened anteriorly and posteriorly. The crista mandibulae externa is relatively low.

R e marks. The described angular differs from those assigned to Pelophylax sp. (see above) in having a smooth rectangular coronoid process. The poor osteological characteristics of the extant species prevent identification of the material to the genus-level.

\section{Order Squamata Oppel, 1811 Suborder Amphisbaenia Gray, 1844}

\section{Amphisbaenia indet. Text-fig. $6 \mathrm{a}$}

Material. One vertebra, EUNHM PV-13238, Nasrettinhoca 1, early Pliocene, MN 14. 


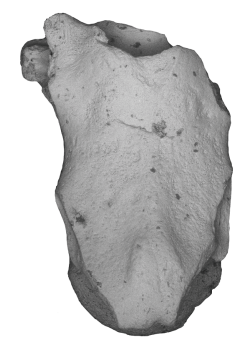

a1

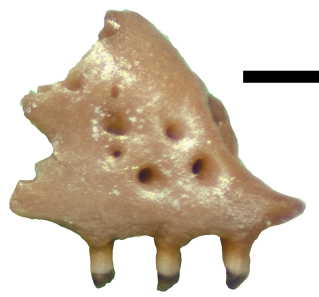

b1

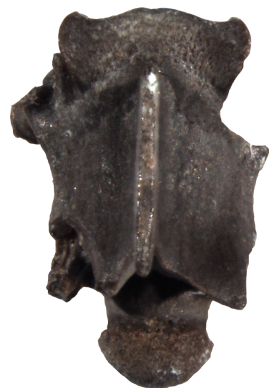

c1

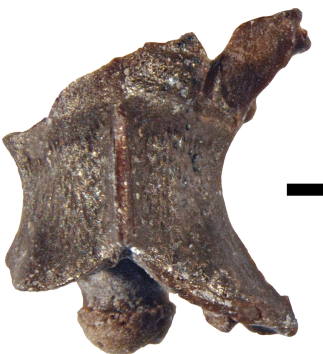

d1

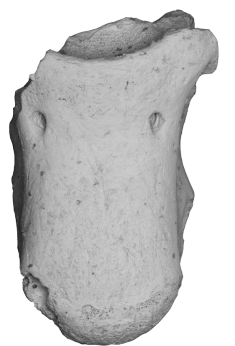

a2

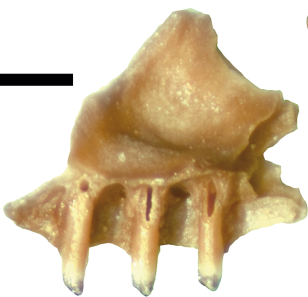

b2

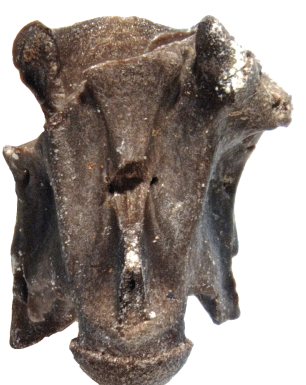

c2

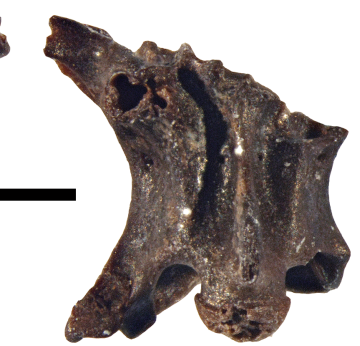

d2

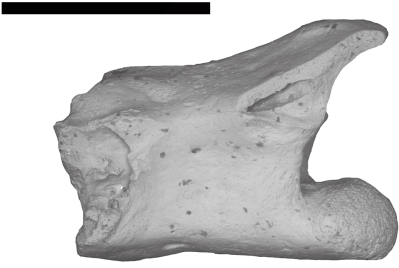

a3

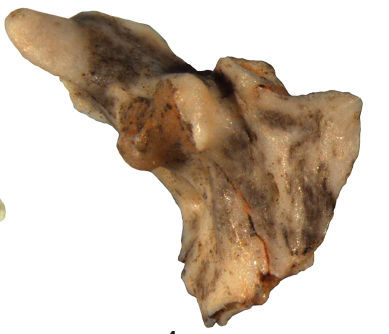

e1

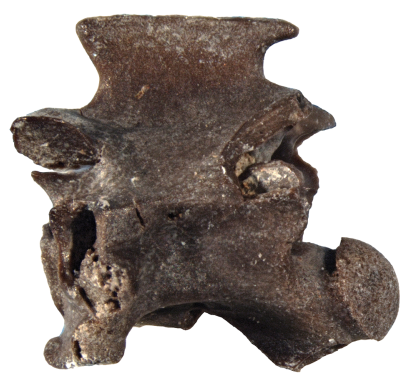

c3

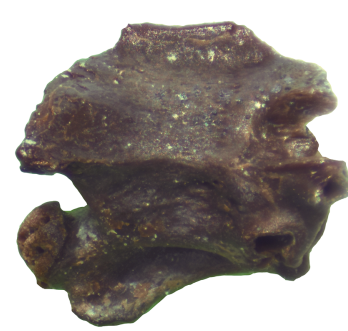

d3

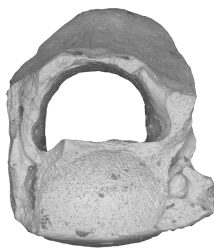

a4

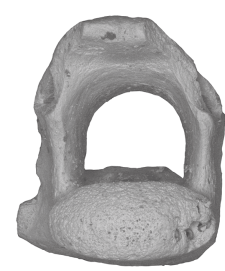

a5

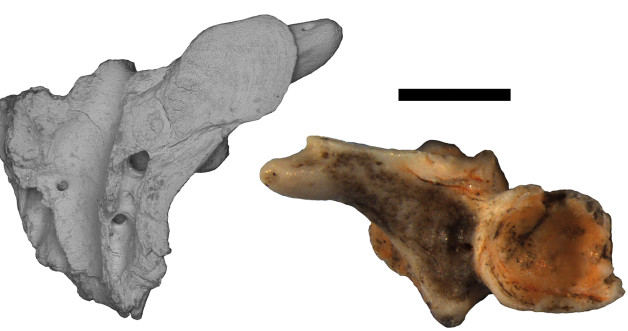

e2

e3

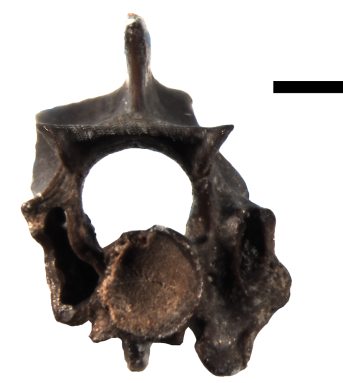

c4

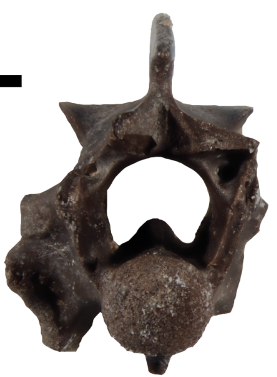

c5

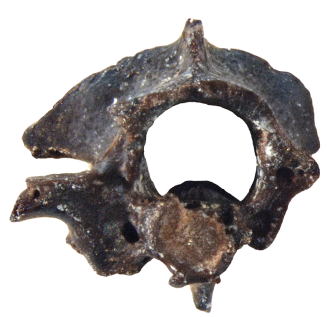

d4

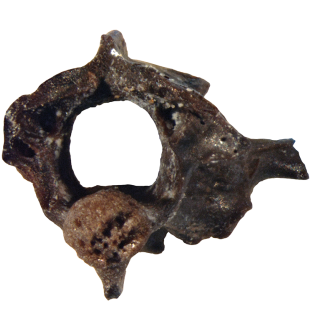

d5

Text-fig. 6. Squamates: a - vertebra of Amphisbaenia indet. from Nasrettinhoca 1, in dorsal (a1), ventral (a2), lateral (a3), anterior (a4), and posterior (a5) views, EUNHM PV-13238; b - right maxilla of Lacertidae indet. from Nasrettinhoca 1, in lateral (b1) and medial (b2) views, EUNHM PV-13239; c - cervical vertebra of Natrix sp. from Hamamkarahisar B, in dorsal (c1), ventral (c2), lateral (c3), anterior (c4), and posterior (c5) views, EUNHM PV-13240; d - trunk vertebra of Natricinae indet. from Nasrettinhoca 2, in dorsal (d1), ventral (d2), lateral (d3), anterior (d4), and posterior (d5) views, EUNHM PV-13241; e - vertebra of cf. Colubrinae indet. from Yenişarbademli, in ventral (e1), dorsal (e2), and anterior (e3) views, EUNHM PV-13262. Scale equals 1 mm.

Description. The presacral vertebra is small (centrum length about $1.5 \mathrm{~mm}$ ) with a centrum that is almost compressed dorsoventrally. The lateral margins of the centrum are almost parallel and divergent anteriorly. The ventral surface of the centrum bears two distinct subcentral foramina. The cotyles and condyles are oval in shape. The neural canal is semicircle in anterior and posterior views and its height is slightly lower than the height of the cotyle. The neural arch is almost smooth dorsally without a neural crest. The arch has a sinusoid shape in lateral aspect, gradually rising towards the posterior end. The anterior edge of the neural arch is deeply convex. The pre- and postzygapophyses are missing (except for a small fragment of the left prezygapophysis).

$\mathrm{R} \mathrm{e} \mathrm{marks}$. The vertebra is too fragmentary to provide any details of their morphology (i.e. morphology of prezygapophyses and synapophyses). The visible features of the specimen generally correspond to those of Anguidae (and Anguis) based on a dorsoventrally compressed centrum and lateral margin of the centrum, which are almost parallel in ventral view (Klembara 1982, Čerňanský et al. 2019). However, Anguidae are characterized by the vertebrae 
having a clear neural spine and generally a larger size. The specimen from Nasrettinhoca 1 lacks a neural spine, its arch has a sinusoidal shape in lateral view, with a convex anterior edge in dorsal view, which support referral to an amphisbaenian (Estes 1983). Amphisbaenia is widely distributed in modern day Turkey where the Blanus strauchi species complex is known (Sindaco et al. 2014). Though the record from Nasrettinhoca 1 probably belongs to Blanus (and to Blanus strauchi species complex), the poor preservation of the material prevents precise identification.

\section{Family Lacertidae BonAPARTe, 1831}

\section{Lacertidae indet. Text-fig. $6 b$}

Material. One maxilla, EUNHM PV-13239, Nasrettinhoca 1, early Pliocene, MN 14.

Description. The maxilla is incomplete and represented by a fragment of its anterior part. It bears pleurodont teeth. Only three teeth are preserved. All teeth are cylindrical, slender, and vertical; their bases are not expanded. The height of the teeth does not exceed approximately $1 \mathrm{~mm}$. The tooth apices are bicuspid.

Remarks. The fragmentary maxilla from Nasrettinhoca 1 clearly shows the typical character of Lacertidae, i.e. the pleurodont bicuspid teeth (e.g. Estes et al. 1988). Lacertidae are highly abundant and variable in the region of modern day Turkey. This makes the identification of fragmentary material such as the specimen from Nasrettinhoca 1 problematic. The small size of the maxilla would suggest the presence of a relatively small-sized taxon.

\section{Family Colubridae OPPEL, 1811}

\section{Genus Natrix LAURENTI, 1768}

\section{Natrix sp.}

Text-fig. 6c

M a t e r i a l. One cervical vertebra, EUNHM PV-13240, Hamamkarahisar B, early Pliocene, MN 14.

$\mathrm{D}$ e s c r i p t i o $\mathrm{n}$. The specimen is represented by a single incomplete cervical vertebra. The vertebra is procoelous with an elongated centrum. The cotyle and condyle are circular. The neural spine is distinctly high, overhanging slightly anteriorly and strongly posteriorly. Although broken, the hypapophysis is directed ventrally rather than posteriorly. The parapophyses and diapophyses are preserved only on the left side. They are separated from each other. The parapophyseal processes are long and horizontally oriented, with rounded tips, and distinctly protrude anteriorly from the centrum.

R e m a r k s. The vertebra from Hamamkarahisar B can be identified as Natricinae (sensu Szyndlar 1991a) based on the following combination of features: presence of strong subcentral ridges and a hypapophysis. Cervicals of Natrix, have a distinctly high neural spine, which overhangs slightly anteriorly and strongly posteriorly (Szyndlar 1984). But the parapophyseal processes of the vertebra are horizontally oriented (in contrast to antero-ventrally oriented parapophyseal processes in cervicals of Natrix). The morphology of the parapophyseal processes (i.e. its rounded tips) could suggest the presence of $N$. natrix, whereas the parapophyseal processes in Natrix tesselata and $N$. maura have acute tips (Szyndlar 1991a).

\section{Natricinae indet. Text-fig. 6d}

Material. One trunk vertebra, EUNHM PV-13241, Nasrettinhoca 2, early Pliocene, MN 14; 20 vertebrae, EUNHM PV-13242-13261, Yenişarbademli, Middle Pleistocene.

Description. All specimens are incomplete. The hypapophyses are broken off near their bases in each specimen. In ventral view, the centrum bears well-developed subcentral ridges. Small subcentral foraminae are located in both sides of the hypapophysis. The paradiapophyses are differentiated into parapophyseal and diapophyseal portions. The cotyle and condyle are relatively small and circular. The prezygapophyseal facet is longer than it is wide and horizontally oriented. The zygosphene is slightly crenate in dorsal view. The neural spines are usually damaged near their bases, but where partly preserved in a few specimens, they are relatively high. The neural arch is vaulted posteriorly.

Re marks. The described vertebrae can be identified as Natricinae, Elapidae or Viperidae based on the presence of hypapophyses. The vaulted neural arch permits us to refer this vertebra to the Natricinae, but the relatively short centrum is not usual for these snakes.

\section{cf. Colubrinae indet. \\ Text-fig. 6e}

Material. One vertebra, EUNHM PV-13262, Yenişarbademli, Middle Pleistocene.

Description. The specimen is highly fragmentary. The neural arch and posterior portion of the centrum are missing. The parapophysis and diapophysis are separated by a shallow depression. The haemal keel or hypapophysis is preserved only by its anterior half, where it is flattened and widened. The prezygapophyseal articular facet is large and has a relatively oval shape. The prezygapophyseal process is rounded distally and long, up to a third of the width of the prezygapophyseal facet.

Remarks. Although the centrum is incomplete ventrally, it bears a flattened and widened haemal keel/ hypapophysis along the length of the preserved portion. This structure has no midline elevation which is usually present in centra bearing a hypapophysis, therefore the presence of the haemal keel instead of a hypapophysis is most probable here. The specimen from Yenişarbademli can be assigned to Colubrinae (sensu Szyndlar 1991b) due to the combination of the following features: presence of haemal keel and synapophysis clearly divided into diapophysis and parapophysis. The relatively short parapophyseal process also confirms this determination. The poor preservation prevents identification of the material to the generic and specific levels. 


\section{Discussion}

The studied fossil herpetofauna of Turkey is composed mainly of extant genera and species (Text-fig. 7). The only extinct taxa are Latonia and Palaeobatrachus. Latonia (as Latonia sp.) was previously reported only from the Early Pleistocene of Pasinler locality (Vasilyan et al. 2014) and recently from the Early Miocene of Kilçak locality (Syromyatnikova et al. 2019). Other than these examples, Latonia remains were recovered from Oligo - Miocene localities but they are undescribed and unpublished (Claessens 1995). In general, Latonia is poorly known in the Eastern Mediterranean compared with its rich fossil record in Europe. Apart from Turkey, remains of this frog are reported from the early Miocene of Greece (Aliveri and Karydia; Georgalis et al. 2019), as well as Latonia nigriventer (Mendelssohn et Steinitz, 1943) which is known from the Pleistocene to Recent of Israel (Biton et al. 2013, 2016). Similar to Latonia, Palaeobatrachidae (Palaeobatrachus) is essentially a European group. Its Asian (i.e. Western Asia) record includes ?Palaeobatrachidae indet. from the Ericek locality (Pliocene, MN 15; Van den Hoek Ostende et al. 2015a). Undescribed palaeobatrachids are known from the early Miocene of Keseköy (Claessens 1997). In other Near East countries palaeobatrachids are unknown. Palaeobatrachus from Mercan 1 extends the temporal range of this group in the Eastern Mediterranean into the late Pliocene. Thus, remains of Latonia and Palaeobatrachus, very rare frogs in the fossil record of the Middle East, show that these taxa were more widespread in this area than previously thought.

Other taxa revealed in the Pliocene and Pleistocene Turkish localities and described here (i.e. Pelobates sp., Bufotes viridis, Pelophylax sp., Ranidae indet., Amphisbaenia indet., Lacertidae indet., Natrix sp., Natricinae indet., cf. Colubrinae indet.) are extant and widespread in modern day Turkey. However, as fossils they rarely occur in the region and their record here is patchy. In particular, Pelobatidae were previously described only from the late Pliocene of Çalta (as Pelobates sp.; Rage and Sen 1976, Sen and Rage 1979) and P. syriacus was mentioned in the personal communication of S. Bailon from the Middle to Late Pleistocene of Karain E (Blain et al. 2016). The tadpoles of Pelobates are known from the early or middle Miocene of Bes Konak (= Beşkonak) (Rückert-Ülkümen et al. 2002). In other neighboring countries Pelobatidae are also scarce and reported from the late Miocene of Ano Metochi and late Pliocene of Tourkobounia 5 (both Greece; Sanchiz 1998, Georgalis et al. 2017). Bufonidae are known in Turkey starting from the early Miocene (as Bufotes aff. viridis from Keseköy; Claessens 1997), from the late Pliocene (as Bufotes cf. viridis from Çalta; Rage and Sen 1976, Sen and Rage 1979), and from the Middle Pleistocene (as Bufotes viridis from Emirkaya-2; Venczel and Sen 1994). Ranidae are known from the early Miocene (as Pelophylax ex. gr. ridibundus from Alpagut-Dodurga; Rückert-Ülkümen 2003) and from the early or middle Miocene (as Pelophylax barani from Bes Konak; Rückert-Ülkümen 1980). Among the described assemblages Pelophylax are the most common. Rana sp. was listed from the late Pliocene of Çalta. However, this material was not described and figured, and currently (sensu Frost et al. 2006) should be considered only as Ranidae. The Turkish amphisbaenians were described from the middle Miocene (MN 6-8) of Gebeceler locality (as Blanus cf. strauchi; Georgalis et al. 2018) and late Pliocene of Çalta (as Amphisbaenidae indet.; Rage and Sen 1976). Lacertidae (as Lacertidae indet., Lacerta sp. or cf. Lacerta) are reported from the early Pliocene of Çeştepe (Sen et al. 2017), the late Pliocene of Çalta (Rage and Sen 1976), and the Middle Pleistocene of Emirkaya-2 (Venczel and Sen 1994). Natricinae (or Natrix) are represented in Turkish localities of the early Pliocene (Ericek; Van den Hoek Ostende et al. 2015a), Early Pleistocene (Pasinler; Vasilyan et al. 2014), and Middle Pleistocene (Emirkaya-2; Venczel and Sen 1994). In contrast, in Greece Natricinae are known since the early Miocene (Georgalis et al. 2019). Colubrinae

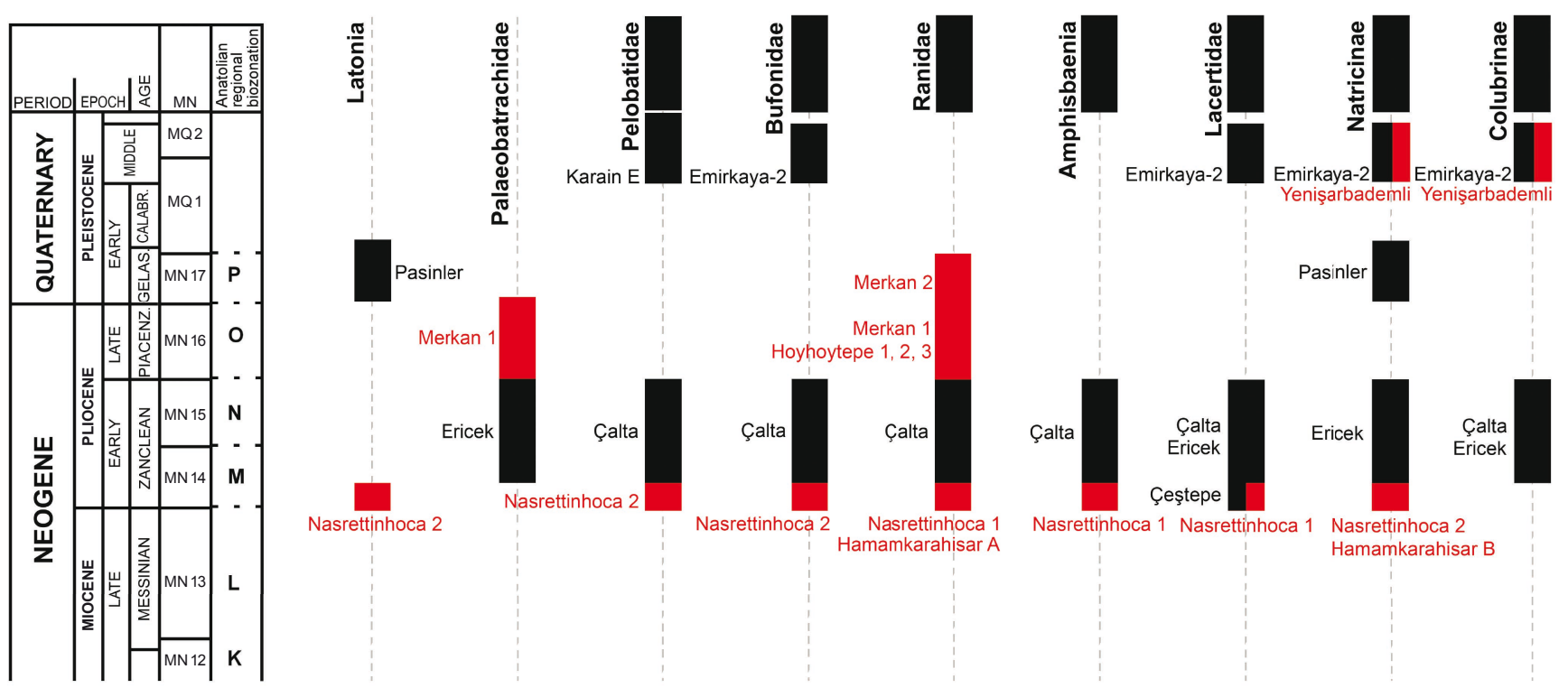

Text-fig. 7. Temporal distribution of the described taxa from the Plio-Pleistocene localities of Turkey. The described localities are marked in red. 
are reported from the late Pliocene (Çalta and Ericek) and the Middle Pleistocene (Emirkaya-2). Among these listed taxa, remains of Pelobatidae, Bufonidae, Ranidae, Amphisbaenia and Natricinae described here are reported from the MN 14 biochron of Turkey (Nasrettinhoca and Hamamkarahisar localities) for the first time.

The assemblage of the Nasrettinhoca localities (i.e. Nasrettinhoca 1, 2; early Pliocene, MN 14) is the most diverse among the described herpetological assemblages and includes four amphibian and three reptile taxa. The only known contemporary assemblages from Çeştepe apparently have a low diversity and include only three taxa of reptiles (Sen et al. 2017). The Nasrettinhoca assemblage is most similar to those of Çalta which is younger in age (MN 15 and, possibly, MN 14), both assemblages share five taxa (Pelobatidae, Bufonidae, Ranidae, Amphisbaenia and Lacertidae). The older herpetological assemblages from Ano Metochi and Maramena localities in Greece (latest Miocene, MN 13) are much more diverse than Nasrettinhoca including more than fifteen taxa of amphibians and three taxa of reptiles each. The Nasrettinhoca assemblage adds to the knowledge of the herpetofaunal composition of this stratigraphic level which up to now was only poorly characterized in Turkey. The herpetological complex of the Hamamkarahisar localities (i.e. Hamamkarahisar A, B) is seemingly the same age as that from Nasrettinhoca, but less diverse and includes only Ranidae and Natricinae. But, the low herpetofaunal diversity in Hamamkarahisar appears artificial. The late Pliocene and Early Pleistocene assemblages (Hoyhoytepe and Mercan localities) yielded only ranid remains (with the exception of a single specimen of Palaeobatrachus from Mercan 1) and most of them belong to the genus Pelophylax. The chronologically similar herpetological assemblage of Pasinler shows a similarly low diversity, but differs from Hoyhoytepe and Mercan in faunal composition, comprising Latonia sp., Natrix sp. and Colubridae indet. (Vasilyan et al. 2014). The Middle Pleistocene fauna of Yenişarbademli locality yielded only snake material of Natricinae and Colubrinae. It can be compared with the coeval assemblage from Emirkaya-2 which is dominated by snakes, but the latter assemblage shows a higher diversity of snakes with eight taxa represented and also includes two lizard and one amphibian taxa.

Though the Pliocene and Pleistocene herpetofauna of Turkey is mostly composed of extant taxa, it seems that the Pliocene - Early Pleistocene fauna of the region is slightly more diverse and abundant in amphibians than the Middle Pleistocene fauna, which is dominated mostly by squamate taxa. However, the difference in faunal compositions between Pliocene and Pleistocene can also reflect different environmental conditions or biases of preservation and collection. The incomplete fossil record of amphibians and reptiles in Turkey, together with a number of yet unpublished records (see M. Böhme and A. Ilg, 2003, fosFARbase, http://www.wahrestaerke.com/ [access date: February 2019]), allows us to expect additional data on the faunal composition from forthcoming studies.

The limited material on small mammals however provided a reliable biochronological base for the study of herpetofauna. The new material on the most primitive vole Promimomys cf. insuliferus gives new evidence that
Anatolia was among the regions where the earliest stages of Arvicolini radiation took place in the early Pliocene (MN 14). The later stage of vole radiation during the later early Pliocene (MN 15) is unfortunately absent in the studied material. On the contrary, the late Pliocene faunal stage (MN 16), the biochronological interval with a not very dense fossil record in Europe, is well represented in the studied assemblages. The index species for the interval, the large size vole Mimomys hajnackensis shows well-developed dentine tracts indicating a later part of the early Villanyian. A single record of small Mimomys ex gr. stehlini-hintoni documents an earliest Pleistocene (MN 17) faunal stage in Anatolia. The fissure-filling fauna of Yenişarbademli records a previously undocumented early Middle Pleistocene chronological level in Turkey with several arvicoline species showing consistently primitive morphological stages ancestral to later Pleistocene and modern forms. Some of these stages, e.g. the larger Microtus cf. guentheri, in future may deserve a chrono-taxon of its own when more material is available.

\section{Conclusions}

The reviewed small vertebrate faunas collected in the 1990s are described for the first time in the published record. The Plio-Pleistocene assemblages of the Eskişehir-Sivrihisar region document two biochronological levels (MN 14 and MN 16a/MN 17) probably separated by a stratigraphic hiatus spanning the late early Pliocene (MN 15). The new data supports the reliability of existing Pliocene-Pleistocene biozonations and refines the biodiversity database of fossil small vertebrates in Anatolia.

\section{Acknowledgements}

We thank the members of the EUNHM who collected small vertebrate faunas between 2000-2012. Roman Rakitov (Borissiak Paleontological Institute RAS, Moscow) is thanked for assistance with SEM microscopy. We thank Hugues-Alexandre Blain (Institut Català de Paleoecologia Humana i Evolució Social) and an anonymous reviewer for their useful comments and corrections, which improved the original version of this paper. E.S. and A.T. were supported by the Russian Foundation for Basic Research nos. 18-05-00746 and 19-04-00514, and the government themes AAAA-A19-119020590095-9 (Zoological Institute of the Russian Academy of Sciences), 0135-2019-0060 (Geological Institute of the Russian Academy of Sciences). S.M. was supported by Ege University (TTM/001/2016) and (TTM/002/2016) research grants as well as the international bilateral research programme TUBITAK-RFBR 111 Y192 during his visits to Russia.

\section{References}

Agajanian, A. K., Kowalski, K. (1978): Prosomys insuliferus (Kowalski, 1958) (Mammalia, Rodentia) from the Pliocene of Poland and of the European Part of the USSR. - Acta Zoologica Cracoviensia, 23(3): 29-53. 
Bailon, S. (1999): Différenciation ostéologique des anoures (Amphibia, Anura) de France. - In: Desse, J., Desse-Berset, N. (eds), Fiches d'ostéologie animale pour l'Archéologie, Série C: Varia, 1. Centre de Recherches Archéologiques-CNRS, Valbonne, pp. 1-41.

Baryshnikov, G. F., Baranova, G. I. (1983): Gryzuny rannego paleolita Bol'shogo Kavkaza [Rodents of the Early Paleolithic in the Greater Caucasus]. - Proceedings of Zoological Institute of the USSR Academy of Sciences, 119: 100-138. (in Russian)

Biton, R., Boistel, R., Rabinovich, R., Gafny, S., Brumfeld, V., Bailon, S. (2016): Osteological observations on the alytid anura Latonia nigriventer with comments on functional morphology, biogeography, and evolutionary history. - Journal of Morphology, 277(9): 1131-1145. https://doi.org/10.1002/jmor.20562

Biton, R., Geffen, E., Vences, M., Cohen, O., Bailon, S., Rabinovich, R., Malka, Y., Oron, T., Boistel, R., Brumfeld, V., Gafny, S. (2013): The rediscovered Hula painted frog is a living fossil. - Nature Communications, 4: 1959 (6 pp.). https://doi.org/10.1038/ncomms2959

Blain, H.-A., Delfino, M., Berto, C., Arzarello, M. (2016): First record of Pelobates syriacus (Anura, Amphibia) in the early Pleistocene of Italy. - Palaeobiodiversity and Palaeoenvironments, 96: 111-124. https://doi.org/10.1007/s12549-015-0220-1

Böhme, G. (1977): Osteologischer Bestimmungsschlüssel für Anuren aus dem Quartär Mitteleuropas. - Wissenschaftliche Zeitschrift der Humboldt-Universität zu Berlin, mathematisch-naturwissenschaftliche Reihe, 26: 283-300.

Böhme, M. (2001): The oldest representative of a brown frog (Ranidae) from the Early Miocene of Germany. Acta Palaeontologica Polonica, 46(1): 119-124.

Boyraz, S. (2004): Mülk-Demirci yöresi (Eskişehir-Sivrihisar) Neojen (Üst Miyosen-Pliyosen) birimlerinin kil mineralojisi [Clay mineralogy of the Neogene (upper Miocene-Pliocene) units around Mülk-Demirci area (Eskişehir-Sivrihisar)]; MSc Thesis. - MS, Ankara University, Ankara, Turkey, 96 pp. (in Turkish) (copy in library of Ankara University)

Bruijn, H. de, Ünay, E., Hordijk, K. (2013): A Review of the Neogene succession of the Muridae and Dipodidae from Anatolia, with special reference to taxa known from Asia and/or Europe. - In: Wang, X., Flynn, L., Fortelius, M. (eds), Fossil Mammals of Asia: Neogene Biostratigraphy and Chronology. Columbia University Press, New York, pp. 566-582. https://doi.org/10.7312/columbia/9780231150125.003.0026

Carls, N., Rabeder, G. (1988): Arvicolids (Rodentia, Mammalia) from the Earliest Pleistocene of Schernfeld (Bavaria). - Beiträge zur Paläontologie von Österreich, 14: 123-237.

Claessens, L. (1995): Miocene Reptilian and Amphibian Faunas of Anatolia; PhD Thesis. - MS, Utrecht University, the Netherlands, 67 pp. (copy in library of Utrecht University)

Claessens, L. (1997): On the herpetofauna of some Neogene Eastern Mediterranean localities and the occurrence of Palaeobatrachus and Bufo in the Lower Miocene of Anatolia. - In: Abstract of Papers, Fifty-Seventh Annual Meeting, Society of Vertebrate Paleontology, October 8-11, Chicago, Illinois, p. 39A.
Çelik, M., Dokuz, U. E., Türköz, P. E., Güllü, Ö., Arslan, Ş. (2013): Hydrogeochemical and Isotopic Investigation of Nasrettin Hoca Springs, Eskişehir, Turkey. - Bulletin of the Mineral Research and Exploration, 146: 93-104.

Čerňanský, A., Vasilyan, D., Georgalis, G. L., Joniak, P., Mayda, S., Klembara, J. (2017): First record of fossil anguines (Squamata; Anguidae) from the Oligocene and Miocene of Turkey. - Swiss Journal of Geosciences, 110(3): 741-751. https://doi.org/10.1007/s00015-017-0272-5

Čerňanský, A., Yaryhin, O., Ciceková, J., Werneburg, I., Hain, M., Klembara, J. (2019): Vertebral comparative anatomy and morphological differences in anguine lizards with a special reference to Pseudopus apodus. The Anatomical Record, 302(2): 232-257. https://doi.org/10.1002/ar.23944

Doukas, C. S., Papayianni, K. (2016): Small Mammals in the Plio/Pleistocene Sediments of Greece. - In: Harvati, K., Roksandic, M. (eds), Paleoanthropology of the Balkans and Anatolia (Vertebrate Paleobiology and Paleoanthropology Series). Springer, Dordrecht, pp. 291-302. https://doi.org/10.1007/978-94-024-0874-4_17

Erdal, O., Erturaç, M. K., Dalfes, N., Sen, S. (2018): Rodents from the Middle Pleistocene of Niksar Basin (Tokat-Turkey): implications on palaeoenvironment and the North Anatolian Fault. - Neues Jahrbuch für Geologie und Paläontologie, Abhandlungen, 289(1): 77-111. https://doi.org/10.1127/njgpa/2018/0751

Estes, R. (1983): Sauria terrestria, Amphisbaenia (Handbuch der Paläoherpetologie, Part 10A). - Gustav Fischer Verlag, Stuttgart, 249 pp.

Estes, R., de Queiroz, K., Gauthier, J. (1988): Phylogenetic relationships within Squamata. - In: Estes, R., Pregill, G. (eds), Phylogenetic Relationships of the Lizard Families. Stanford University Press, Stanford, pp. 119-282.

Fejfar, O., Heinrich, W.-D., Lindsay, E. H. (1998): Updating the Neogene rodent biochronology in Europe. - Mededelingen Nederlands Instituut voor Toegepaste Geowetenschappen TNO, 60: 533-554.

Frost, D. R., Grant, T., Faivovich, J., Bain, R. H., Haas, A., Haddad, C. F. B., de Sá, R. O., Channing, A., Wilkinson, M., Donnellan, S. C., Raxworthy, C. J., Campbell, J. A., Blotto, B. L., Moler, P., Drewes, R., Nussbaum, R. A., Lynch, J. D., Green, D. M., Wheeler, W. C. (2006): The amphibian tree of life. - Bulletin of the American Museum of Natural History, 297: 1-370. https://doi.org/10.1206/0003-0090(2006)297[0001:TATOL]2.0.CO;2

Georgalis, G. L., Halaçlar, K., Mayda, S., Kaya, T., Ayaz, D. (2018): First fossil find of the Blanus strauchi complex (Amphisbaenia, Blanidae) from the Miocene of Anatolia. - Journal of Vertebrate Paleontology, 38(2): e1437044 (6 pp.). https://doi.org/10.1080/02724634.2018.1437044

Georgalis, G. L., Villa, A., Delfino, M. (2017): Fossil lizards and snakes from Ano Metochi - a diverse squamate fauna from the latest Miocene of northern Greece. - Historical Biology, 29(6) 730-742. https://doi.org/10.1080/08912963.2016.1234619

Georgalis, G. L., Villa, A., Ivanov, M., Roussiakis, S., Skandalos, P., Delfino, M. (2019): Early Miocene herpeto- 
faunas from the Greek localities of Aliveri and Karydia - bridging a gap in the knowledge of amphibians and reptiles from the early Neogene of southeastern Europe. - Historical Biology, 31 (8): 1045-1064.

https://doi.org/10.1080/08912963.2017.1417404

Gómez, R. O., Turazzini, G. F. (2016): An overview of the ilium of anurans (Lissamphibia, Salientia), with a critical appraisal of the terminology and primary homology of main ilial features. - Journal of Vertebrate Paleontology, 36(1): e1030023 (12 pp.).

https://doi.org/10.1080/02724634.2015.1030023

Gözler, M. Z., Cevher, F., Ergül, E., Asutay, H. J. (1996): Orta Sakarya ve Güneyinin Jeolojisi [Geology of Central Sakarya and its South]. - MTA Report No. 9973, 87 pp. (in Turkish)

Kahraman, B. (2018): Mihalıççık ve Sivrihisar (Eskişehir, Türkiye) Arasında Kalan Bölgenin Neojen Yapısal Evrimi [Neogene Structural Evolution of the Area Between Mihaliççik and Sivrihisar (Eskişehir, Turkey)]; PhD Thesis. - MS, Hacettepe University, Ankara, Turkey, 123 p. (in Turkish) (copy in library of Hacettepe University)

Karakaş, Z., Varol, B., Boyraz, S. (2007): Clay Mineralization of the Neogene Aged Volcanics of the Northeastern Sivrihisar (Mülk-Demirci). - Bulletin of the Mineral Research and Exploration, 134: 1-16.

Klembara, J. (1982): Beitrag zur Kenntnis der Subfamilie Anguinae. - Acta Universitatis Carolinae, Geologica, 1981(2): 121-168.

Koufos, G. D. (2001): The Villafranchian mammalian faunas and biochronology of Greece. -Bollettino della Società Paleontologica Italiana, 40(2): 217-223.

Kowalski, K. (1956): Insectivores, bats and rodents from the early Pleistocene bone breccia of Podlesice near Kroczyce (Poland). - Acta Paleontologica Polonica, 1: 331-394.

Kryštufek, B., Vohralik, V. (2005): Mammals of Turkey and Cyprus. Rodentia I: Sciuridae, Dipodidae, Gliridae, Arvicolinae. - University of Primorska, Koper, 292 pp.

Kuss, S. E., Storch, G. (1978): Eine Säugetierfauna (Mammalia: Artiodactyla, Rodentia) des älteren Pleistozäns von der Insel Kalymnos (Dodekanés, Griechenland). - Neues Jahrbuch für Geologie und Paläontologie, Abhandlungen, 4: 206-227.

Maul, L. Parfitt, S. (2010): Micromammals from the 1995 Mammoth Excavation at West Runton, Norfolk, UK: Morphometric data, biostratigraphy and taxonomic reappraisal. - Quaternary International, 228: 91-115. https://doi.org/10.1016/j.quaint.2009.01.005

Mayhew, D. F. (1978): Late Pleistocene small mammals from Arnissa (Macedonia, Greece). - Proceedings of the Koninklijke Nederlandse Akademie van Wetenschappen, ser. B., 81(3): 302-321.

Meszoely, C. A. M., Špinar, Z. V., Ford, R. L. E. (1984): A new palaeobatrachid frog from the Eocene of the British Isles. - Journal of Vertebrate Paleontology, 3: 143-147. https://doi.org/10.1080/02724634.1984.10011967

Montuire, S., Sen, S., Michaux, J. (1994): The Middle Pleistocene mammalian fauna from Emirkaya-2, Central Anatolia (Turkey): Systematics and paleoenvironment. Neues Jahrbuch für Geologie und Paläontologie, Abhandlungen, 193(1): 107-144.
Rabeder, G. (1981): Die Arvicoliden (Rodentia, Mammalia) aus dem Pliozän und dem älterem Pleistozän von Niederösterreich. - Beiträge zur Paläontologie von Österreich, 8: 1-343.

Rage, J.-C., Sen, S. (1976): Les Amphibiens et les Reptiles du Pliocene superieur de Calta (Turquie). - Geologie mediterraneenne, 3: 127-134.

https://doi.org/10.3406/geolm.1976.969

Ratnikov, V. Yu. (2001): Osteology of Russian toads and frogs for paleontological researches. - Acta Zoologica Cracoviensia, 44: 1-23.

Rekovets, L. I., Nadachowski, A. (1995): Pleistocene voles (Arvicolidae) of the Ukraine. - Paleontologia i Evolucio, 28-29: 145-245.

Roček, Z. (1984): Lizards (Reptilia: Sauria) from the Lower Miocene locality Dolnice (Bohemia, Czechoslovakia). Rozpravy Československé akademie věd, Řada matematických a prrírodních věd, 94(1): 1-69.

Roček, Z. (2013): Mesozoic and Tertiary Anura of Laurasia. - Palaeobiodiversity and Palaeoenvironments, 93: 397-439. https://doi.org/10.1007/s12549-013-0131-y

Roček, Z., Wuttke, M., Gardner, J. D., Singh Bhullar, B.-A. S. (2014): The Euro-American genus Eopelobates, and a re-definition of the family Pelobatidae (Amphibia, Anura). - Palaeobiodiversity and Palaeoenvironments, 94: 529-567. https://doi.org/10.1007/s12549-014-0169-5

Rörig, G., Börner, C. (1905): Studien über das Gebiss mitteleuropäischer recenter Mäuse. - Arbeiten aus der Kaiserlichen Biologischen Anstalt für Land und Forstwirtschaft, Berlin, 5: 37-89.

Rückert-Ülkümen, N. (1980): Fossile Fische und Frösche aus dem höheren Miozän von Zentralanatolien. - Ege Üniversitesi Fen Fakültesi Ilmî Raporlar Serisi, 249: $1-14$.

Rückert-Ülkümen, N. (2003): Fossil ranids from Miocene deposits of Central Anatolia - Istanbul Üniversitesi Mühendislik Yerbilimleri Dergisi, 16(2): 71-74.

Rückert-Ülkümen, N., Maus, M., Glaw, F., Franzen, M. (2002): Kaulquappen von Pelobates sp. (Amphibia: Pelobatidae) aus dem Miozän von Beşkonak Köyü, Zentralanatolien, Türkei. - Mitteilungen der Bayerischen Staatssammlung für Paläontologie und historische Geologie, 42(1): 75-82.

Sanchiz, B. (1984): Análisis filogenético de la tribu Alytini (Anura, Discoglossidae) mediante el estudio de su morfoestructura ósea [Phyllogenetic analyses of the Alytini tribe (Anura, Discoglossidae) by means of the study of the osseous morphostructure]. - In: Hemmer, H., Alcover, J. A. (eds), Història biològica del Ferreret. Editorial Moll, Ciutat de Mallorca, pp. 61-108. (in Spanish)

Sanchiz, B. (1998): Salientia (Handbuch der Paläoherpetologie, Part 4). - Verlag Dr. Friedrich Pfeil, München, 275 pp.

Santel, W., Koenigswald, W. von (1998): Preliminary report on the middle Pleistocene small mammal fauna from Yarimburgaz Cave in Turkish Thrace. - Eiszeitalter und Gegenwart, 48: 162-169.

Sen, S. (1977): La fauna de Rongeurs pliocenes de Çalta (Ankara, Turquie). - Bulletin du Muséum national d'histoire naturelle, 3 sér., 465, Sciences de la terre, 61: 89-171. 
Sen, S., de Bonis, L., Dalfes, N., Geraads, D., Jaeger, J.-J., Mazin, J.-M. (1991): Première decouvérte d'un site à mammifères pléistocénes dans une fissure karstique en Anatolie centrale. - Comptes Rendus de l'Academie des Sciences, Série II, 313(1): 127-132.

Sen, S., Delfino, M., Kazanci, N. (2017): Çeştepe, a new early Pliocene vertebrate locality in Central Anatolia and its stratigraphic context. - Annales de Paléontologie, 103(2): 149-163.

https://doi.org/10.1016/j.annpal.2017.01.004

Sen, Ş., Rage, J.-C. (1979): Çalta (Ankara) Pliyosen Omurgalı Faunası [Pliocene vertebrate fauna of Çalta (Ankara)]. - Türkiye Jeoloji Kurumu Bülteni, 22: 155-160. (in Turkish)

Sickenberg, O., Becker-Platen, J. D., Benda, L., Engesser, B., Gaziry, W., Heissig, K., Hunermann, K. A., Sondaar, P. Y., Schmidt-Kittler, N., Staesche, K., Staesche, U., Steffens, P., Tobien, H. (1975): Die Gliederung des höheren Jungtertiärs und Altquartärs in der Türkei nach Vertebraten und ihre Bedeutung für die internationale Neogen-Stratigraphie. - Geologisches Jahrbuch, Reihe B, 15: 1-167.

Sindaco, R., Kornilios, P., Sacchi, R., Lymberakis, P. (2014): Taxonomic reassessment of Blanus strauchi (BEDRIAGA, 1884) (Squamata: Amphisbaenia: Blanidae), with the description of a new species from south-east Anatolia (Turkey). - Zootaxa, 3795(5): 311-326. https://doi.org/10.11646/zootaxa.3795.3.6

Storch, G. (1975): Eine mittelpleistozäne Nager-Fauna von der Insel Chios, Ägäis (Mammalia: Rodentia). - Senckenbergiana Biologica, 56(4-6): 165-189.

Storch, G. (1988): Eine jungpleistozäne/altholozäne NagerAbfolge von Antalya, SW-Anatolien (Mammalia, Rodentia). - Zeitschrift für Säugetierkunde, 53: 76-82.

Stöck, M., Moritz, C., Hickerson, M., Frynta, D., Dujsebayeva, T., Eremchenko, V., Macey, J. R., Papenfuss, T. J., Wake, D. B. (2006): Evolution of mitochondrial relationships and biogeography of Palearctic green toads (Bufo viridis subgroup) with insights in their genomic plasticity. - Molecular Phylogenetics and Evolution, 41: 663-689. https://doi.org/10.1016/j.ympev.2006.05.026

Stöck, M., Sicilia, A., Belfiore, N. M., Buckley, D., Lo Brutto, S., Lo Valvo, M., Arculeo, M. (2008): Post-Messinian evolutionary relationships across the Sicilian channel: mitochondrial and nuclear markers link a new green toad from Sicily to African relatives. - BMC Evolutionary Biology, 8: 56 (19 pp.).

https://doi.org/10.1186/1471-2148-8-56

Suata-Alpaslan, F. (2011): Some small mammal fossils of Üçağızlı Cave (Hatay, Turkey). - Turkish Journal of Zoology, 35(3): 755-768.

Suata-Alpaslan, F. (2015): Promimomys enginae nov. sp. (Arvicolidae, Mammalia) from the Early Pliocene locality Dinar-Akcakoy (Afyon, Turkey). - In: Čepek, A., et al. (eds), Conference proceedings, $15^{\text {th }}$ International multidisciplinary scientific geoconference SGEM2015. Science and technologies in geology, exploration and mining. Volume I. June 18-24 2015, Albena, Bulgaria, pp. 385-394.

Suata-Alpaslan, F., Ünay, E., Ay, F. (2010): İğdeli (Gemerek, Sivas) Lokalitesi Erken Pliyosen Fauna Istifinin Rodentia ve Lagomorpha (Mammalia) Fosilleri: Biyokronolo- jik ve Paleobiyocografik Anlamlari [The Rodentia and Lagomorpha (Mammalia) from the Early Pliocene from İğdeli (Gemerek, Sivas): biocronological and palaeogeographical implications]. - Cumhuriyet Üniversitesi Fen-Edebiyat Fakültesi Fen Bilimleri Dergisi, 31(1): 1-29. (in Turkish)

Syromyatnikova, E., Georgalis, G. L., Mayda, S., Kaya, T., Saraç, G. (2019): A new early Miocene herpetofauna from Kilçak, Turkey. - Russian Journal of Herpetology, 26: 205-224.

https://doi.org/10.30906/1026-2296-2019-26-4-205-224

Szyndlar, Z. (1984): Fossil snakes from Poland. - Acta Zoologica Cracoviensia, 28(1): 1-156.

Szyndlar, Z. (1991a): A review of Neogene and Quaternary snakes of central and eastern Europe. Part 2: Natricinae, Elapidae, Viperidae. - Estudios Geologicos, 47(3-4): 237-266.

https://doi.org/10.3989/egeol.91471-2412

Szyndlar, Z. (1991b): A review of Neogene and Quartarnary snakes of Central and Eastern Europe. Part I: Scolecophidia, Boidae, Colubrinae. - Estudios Geologicos, 47(1-2): 103-126. https://doi.org/10.3989/egeol.91471-2412

Ünay, E., de Bruijn, H. (1998): Plio-Pleistocene rodents and lagomorphs from Anatolia. - Mededelingen Nederlands Instituut voor Toegepaste Geowetenschappen TNO, 60: 431-466.

Ünay, E., de Bruijn, H., Saraç, G. (2003): A preliminary zonation of the continental Neogene of Anatolia based on rodents. - In: Reumer, J. W. F., Wessels, W. (eds), Distribution and migration of Neogene mammals in Eurasia. Deinsea, 10: 530-547.

Van den Hoek Ostende, L. W., van Bennekom, L., Gardner, J. D., Alçiçek, M. C., Murray, A., Wesselingh, F. P., Alçiçek, H., Tesakov, A. (2015a): Ericek, a new Pliocene vertebrate locality in the Çameli Basin (southwestern Anatolia, Turkey). - Palaeobiodiversity and Palaeoenvironments, 95: 305-320. https://doi.org/10.1007/s12549-015-0202-3

Van den Hoek Ostende, L. W., Diepeveen, F., Tesakov, A., Saraç, G., Mayhew, D., Alçiçek, M. C. (2015b): On the brink: micromammals from the latest Villanyian from Biçakçi (Anatolia). - Geological Journal, 50(3): 230-245. https://doi.org/10.1002/gj.2622

Van der Meulen, A. (1973): Middle Pleistocene smaller mammals from the Monte Peglia (Orivieto, Italy) with special reference to the phylogeny of Microtus (Arvicolidae, Rodentia). - Quaternaria, 17: 1-144.

Vasilyan, D., Schneider, S., Bayraktutan, M. S., Şen, Ş. (2014): Early Pleistocene freshwater communities and rodents from the Pasinler Basin (Erzurum Province, north-eastern Turkey). - Turkish Journal of Earth Sciences, 23(3): 1-15. https://doi.org/10.3906/yer-1307-16

Venczel, M., Sen, S. (1994): Pleistocene amphibians and reptiles from Emirkaya-2, Turkey. - Herpetological Journal, 4: 159-165.

Venczel, M., Codrea, V., Fărcaş, C. (2013): A new palaeobatrachid frog from the early Oligocene of Suceag, Romania. - Journal of Systematic Palaeontology, 11(2): 179-189. https://doi.org/10.1080/14772019.2012.671790 